\title{
POLISH BIBLIOGRAPHY OF OCCUPATIONAL MEDICINE, 2010
}

\section{GRAŻYNA KOWALCZYK}

Nofer Institute of Occupational Medicine, Łódź, Poland

Department of Knowledge Management

\section{ASSESSMENT OF OCCUPATIONAL HYGIENE}

1. Augustyn A, Pierchała M. Noise damper for intake and exhaust hoods for cooperation with high-power fans. Bezpiecz Pr 2010;3:28-30, 6 ref. [in Polish].

2. Bieńkowski P, Zubrzak B. Technical possibilities of estimating the environmental exposure to electromagnetic fields for biomedical investigations based on cellular telephony systems. Med Pr 2010;61(2):233-9, 9 ref. [in Polish].

3. De Lucca AJ, Boue SM, Carter-Wientjes $\mathrm{CH}$, Bland JM, Bhatnagar D, Cleveland TE. Volatile profiles of toxigenic and non-toxigenic Aspergillus flavus using SPME for solid phase extraction. Ann Agric Environ Med 2010;17(2):301-8, 15 ref.

4. Derkacz A, Poręba R, Doroszko A, Magott-Derkacz A, Steinmetz-Beck A, Szełemej R, et al. Can angiography system with large-area flat digital panel induce higher irradiation in a patient during coronary angiography. Med Pr 2010;61(5):521-5, 11 ref. [in Polish].

5. Drobnik M, Latour T, Sziwa D. The assessment of health exposure resulted from barium, boron and fluoride intake from therapeutic waters available for resident people in water abstraction points of health resorts. Rocz Panstw Zakl Hig 2010;61(4):373-8, 20 ref. [in Polish].
6. Foltyn M. The usefulness of AFS specimen in eliminating asbestos - laboratorial research. Bezpiecz Pr 2010;2:24-5, 6 ref. [in Polish].

7. Gawęda E. Cobalt and its compounds - a determination method. Podst Met Oceny Srod Pr 2010;26(1): 163-7 [in Polish].

8. Gawęda E. Magnesium oxide - a determination method. Podst Met Oceny Srod Pr 2010;26(1):221-6 [in Polish].

9. Gawęda E. New methods of signifying chemical substances (3). Bezpiecz Pr 2010;12:25-7, 7 ref. [in Polish].

10. Góralczyk K, Struciński P, Hernik A, Czaja K, Korcz W, Snopczyński T, et al. The role and tasks of the National Reference Laboratory in the scope of pesticide residues in food. Rocz Panstw Zakl Hig 2010;61(4):349-54, 14 ref. [in Polish].

11. Górny RL. Biological aerosols - a role of hygienic standards in the protection of environment and health. Med Srod 2010;13(1):41-51, 15 ref. [in Polish].

12. Harazin B. Comparison of recovery time in a cold provocation test performed according to Polish requirements and ISO 14835-1 standard. Med Pr 2010;61(4): 413-7, 16 ref. [in Polish].

13. Harazin B. Acoustical parameters of toys. Med Pr 2010;61(6):649-54, 24 ref. [in Polish].

Received: September 1, 2011. Accepted: September 10, 2011.

Address reprint request to G. Kowalczyk, Scientific Library, Nofer Institute of Occupational Medicine, św. Teresy 8, 91-348 Łódź, Poland (e-mail: kogra@imp.lodz.pl). The wording of titles as in the original publications or their official translations. 
14. Jankowska E, Pośniak M. Concentration and size distribution of Diesel fume particles in garage air. Bezpiecz Pr 2010;1:23-7, 10 ref. [in Polish].

15. Jeżewska A.n-Butane - a determination method. Podst Met Oceny Srod Pr 2010;26(1):107-12 [in Polish].

16. Jeżewska A, Buszewski B. 4-Aminobiphenyl a determination method. Podst Met Oceny Srod Pr 2010;26(1):101-6 [in Polish].

17. Jeżewska A, Buszewski B. 4,4'-Methylenebis(2-chloroaniline) - a determination method. Podst Met Oceny Srod Pr 2010;26(1):125-30 [in Polish].

18. Kantor I, Żera J, Młyński R, Kozłowski E, Wojdas A, Jurkiewicz D. Exposure to noise during military service still a challenge. Lek Wojsk 2010;88(2):97-102, 12 ref. [in Polish].

19. Kowalska J. Tetraethyl silicate - a determination method. Podst Met Oceny Srod Pr 2010;26(1):193-8 [in Polish].

20. Krogulski A, Szczotko M. Microbiological quality of indoor air in dentist's offices. Rocz Panstw Zakl Hig 2010;61(1):99-102, 8 ref. [in Polish].

21. Krogulski A, Szczotko M. Microbial air purity in hospitals. Operating theatres with air conditioning system. Rocz Panstw Zakl Hig 2010;61(4):425-9, 8 ref. [in Polish].

22. Krukowicz T. Electronic signal device supporting prevention of exposure of earmuff users to noise. Bezpiecz Pr 2010;12:19-21, 13 ref. [in Polish].

23. Kucharska M, Wesołowski W, Gromiec J. 2-Metoxyethyl acetate - a determination method. Podst Met Oceny Srod Pr 2010;26(1):185-92 [in Polish].

24. Kupczewska-Dobecka M, Czerczak S, Jakubowski M, Maciaszek P, Janasik B. Application of predictive model to estimate concentrations of chemical substances in the work environment. Med Pr 2010;61(3):307-14, 6 ref. [in Polish].

25. Ławniczek-Wałczyk A, Górny RL. Endotoxins and $\beta$-glucans as markers of microbiological contamination - characteristics, detection, and environmental exposure. Ann Agric Environ Med 2010;17(2):193-208, 194 ref.

26. Marchlik WD, Kurnatowski P. Fungi as pathogens in nosocomial infections. Otorynolaryngologia 2010;9(2):50-4, 32 ref. [in Polish].

27. Mikołajczyk U, Bujak-Pietrek S, SzadkowskaStańczyk I. Exposure to silica dust in coal-mining. Analysis based on measurements made by industrial hygiene laboratories in Poland, 2001-2005. Med Pr 2010;61(3):287-97, 28 ref. [in Polish].

28. Morzyński L, Krukowicz T. Microprocessor dosimetric indicator for monitoring exposure to noise at work. Bezpiecz Pr 2010;11:24-6, 6 ref. [in Polish].

29. Oborska-Kumaszyńska D, Wiśniewska-Kubka S. Analog and digital systems of imaging in roentgenodiagnostics. Pol J Radiol 2010;75(2):73-81, 9 ref.

30. Olszewski J, Kacprzyk J, Kamiński Z. Assessment of radiation exposure of miners to radon and its daughter products in selected non-ferrous metal mines. Med Pr 2010;61(6):635-9, 15 ref. [in Polish].

31. Pawlak A. New requirements included in the draft of the European lighting standard. Bezpiecz Pr 2010;10: 22-5, 6 ref. [in Polish].

32. Rohm-Rodowald E, Jakimiak B, Podgórska M, Chojecka A. Microbiological assessment of efficiency chemothermal disinfection of blood contaminated hospital textiles. Rocz Panstw Zakl Hig 2010;61(3):329-33, 11 ref. [in Polish].

33. Romanowicz B, Gromiec J. 1,3-Dichloropropanol-2 a determination method I and II. Podst Met Oceny Srod Pr 2010;26(1):113-24 [in Polish].

34. Romanowicz B, Gromiec J. Chloromethyl methyl ether - a determination method. Podst Met Oceny Srod Pr 2010;26(1):139-45 [in Polish].

35. Romanowicz B, Gromiec J. 2-Ethoxyethanole a determination method. Podst Met Oceny Srod Pr 2010;26(1):147-53 [in Polish]. 
36. Romanowicz B, Gromiec J. 2-Methoxyethanole a determination method. Podst Met Oceny Srod Pr 2010;26(1):169-75 [in Polish].

37. Sawair FA, Hassoneh Y, Jamleh AO, Al-Rabab'ah M. Observance of proper mercury hygiene practices by Jordanian general dental practitioners. Int J Occup Med Environ Health 2010;23(1):47-54, 28 ref. DOI: 10.2478/ v10001-010-0012-9.

38. Sierocka A, Cianciara M. Monitoring of nosocomial infections. Probl Hig Epidemiol 2010;91(2):323-8, 17 ref. [in Polish].

39. Sitkowska J, Szymańska J, Cholewa G. Studies of microbiological contamination of water from dental units in rural dental practices. Zdrow Publiczne 2010;120(4): 396-9, 21 ref.

40. Solecki L. Assessment of annual exposure of private farmers to the whole body mechanical vibration on selected family farms of animal production profile. Med Pr 2010;61(2):143-54, 35 ref. [in Polish].

41. Solecki L. Assessment of annual exposure of private farmers to whole body mechanical vibration on selected family farms of plant production profile. Ann Agric Environ Med 2010;17(2):243-50, 35 ref.

42. Stojek NM. Enterobacteriaceae and other gram-negative bacteria in water from farm water pipes. Med Srod 2010;13(3):31-40, 24 ref. [in Polish].

43. Suproniene S, Justesen AF, Nicolaisen M, Mankeviciene A, Dabkevicius Z, Semaskiene R, et al. Distribution of trichothecene and zearalenone producing Fusarium species in grain of different cereal species and cultivars grown under organic farming conditions in Lithuania. Ann Agric Environ Med 2010;17(1):79-86, 42 ref.

44. Surgiewicz J. Potassium hydroxide - a determination method. Podst Met Oceny Srod Pr 2010;26(1): 237-42, 1 ref. [in Polish].

45. Surgiewicz J. Selected aspects of occupational safety in production and processing of PVC. Bezpiecz Pr 2010;10:26-9, 12 ref. [in Polish].
46. Szewczyńska M, Osytek A, Pośniak M, Galwas-Grzeszkiewicz M. Diprophyllinum - a determination method. Podst Met Oceny Srod Pr 2010;26(1):131-7 [in Polish]. 47. Szewczyńska M, Osytek A, Pośniak M, GalwasGrzeszkiewicz M. N-Hydroxyurea - a determination method. Podst Met Oceny Srod Pr 2010;26(1):155-62 [in Polish].

48. Szewczyńska M, Osytek A, Pośniak M, Galwas-Grzeszkiewicz M. Sulphyryde - a determination method. Podst Met Oceny Srod Pr 2010;26(1):205-12 [in Polish].

49. Szwajkowska-Michałek L, Stuper K, Łakomy P, Matysiak A, Perkowski J. Contents of microscopic fungi in dusts coming from cereal analysis laboratories. Ann Agric Environ Med 2010;17(1):101-6, 45 ref.

50. Wesołowski W, Kucharska M. Thioacetamide a determination method. Podst Met Oceny Srod Pr 2010;26(1):213-9 [in Polish].

51. Wesołowski W, Kucharska M, Gromiec J. 2-Ethoxyethyl acetate - a determination method. Podst Met Oceny Srod Pr 2010;26(1):177-83 [in Polish].

52. Wesołowski W, Kucharska M, Gromiec J. Hydrogenated terphenyls - a determination method. Podst Met Oceny Srod Pr 2010;26(1):227-36 [in Polish].

53. Wieczorek A, Spałek J, Kwaśny M. The role of lubrication and angular velocity in reducing the noise accompanying operation of gear transmissions. Bezpiecz Pr 2010;7-8:43-5, 8 ref. [in Polish].

54. Wiszniewski A. Environment of air-ions in ship cabins and possibility of its optimization. Med Pr 2010;61(3):299-306, 14 ref. [in Polish].

55. Wlazło A, Górny R, Niesler A, Lis DO, ŁawniczekWałczyk A. Biological agents at the work environment of librarians and archivistes. Pr Zdrow Bezpiecz 2010;2: 5-10, 29 ref. [in Polish].

56. Woźnica A. Propane - a determination method. Podst Met Oceny Srod Pr 2010;26(1):199-204 [in Polish].

57. Wu FFS, Wu MW, Chang CF, Lai SM, Pierse N, Crane J, et al. Endotoxin and $\beta$-(1,3)-glucan 
levels in automobiles: A pilot study. Ann Agric Environ Med 2010;17(2): 327-30, 22 ref.

\section{EXPERIMENTAL PATHOLOGY}

1. Asagba SO. Alteration in the activity of oxidative enzymes in the tissues of male Wistar albino rats exposed to cadmium. Int J Occup Med Environ Health 2010;23(1): 55-62, 35 ref. DOI: 10.2478/v10001-010-0002-y.

2. Asman M, Solarz K, Szilman E, Szilman P.Analysis of expression and amino acid sequence of the allergen Mag 3 in two species of house dust mites - Dermatophagoides farinae and D. pteronyssinus (Acari: Astigmata: Pyroglyphidae). Ann Agric Environ Med 2010;17(1):45-8, 18 ref.

3. Bąk M. Evoked potentials - effect of filter type on the results. Med Pr 2010;61(5):513-9, 14 ref. [in Polish].

4. Bąk M, Dudarewicz A, Zmyślony M, ŚliwińskaKowalska M. Effects of GSM signals during exposure to event related potentials (ERPS). Int J Occup Med Environ Health 2010;23(2):191-9, 33 ref. DOI: 10.2478/ v10001-010-0021-8.

5. Bąk M, Zmyślony M. Effects of electromagnetic field from cellular phones on selected central nervous system functions: a literature review. Med Pr 2010;61(6): 671-83, 71 ref. [in Polish].

6. Chakraborty D, Verma R. Ameliorative effect of Emblica officinalis aqueous extract on ochratoxin-induced lipid peroxidation in the kidney and liver of mice. Int J Occup Med Environ Health 2010;23(1):63-73, 51 ref. DOI: 10.2478/v10001-010-0009-4.

7. Chojecka A, Jakimiak B, Rohm-Rodowald E, Podgórska M. The effect of antibacterial substances on spread resistance of bacteria. Przegl Epidemiol 2010;64(4): 513-7, 23 ref. [in Polish].

8. Cieszczyk P, Maciejewska A, Sawczuk M, Ficek K, Eider J, Jascaniene N. The angiotensin converting enzyme gene I/D polymorphism in ellite Polish and Lithuanian judo players. Biol Sport 2010;27(2):119-22, 25 ref.
9. Cisak E, Wójcik-Fatla A, Zając V, Sroka J, Buczek A, Dutkiewicz J. Prevalence of tick-borne encephalitis virus (TBEV) in samples of raw milk taken randomly from cows, goats and sheep in Eastern Poland. Ann Agric Environ Med 2010;17(2):283-6, 27 ref.

10. Dobrzyńska MM, Radzikowska J. Frequency of micronuclei in reticulocytes of male mice exposed to bisphenol $A$ and to a combination of $X$-rays and bisphenol $A$. Rocz Panstw Zakl Hig 2010;61(2):129-33, 31 ref. [in Polish].

11. Dobrzyńska MM, Tyrkiel EJ, Derezińska E, Ludwicki JK. Is concentration and motility of male gametes related to DNA damage measured by comet assay? Ann Agric Environ Med 2010;17(1):73-7, 39 ref.

12. Dobrzyńska MM, Tyrkiel EJ, Hernik A, Derezińska E, Góralczyk K, Ludwicki JK. The effects of di-n-butyl phthalate on the somatic cells of laboratory mice. Rocz Panstw Zakl Hig 2010;61(1):13-9, 33 ref. [in Polish].

13. Dworzański W, Burdan F, Potembska E, Tomaszewski M, Tomaszewska M, Olchowik G. Caffeine and osteoporosis. Zdrow Publiczne 2010;120(1):93-6, 18 ref. [in Polish].

14. Gralewicz S, Świercz R, Lutz P, Wiaderna D, Wassowicz W. Effects of stress pretreatment on the $d y$ namics of blood cholinesterase activity after exposure to an organophosphorus pesticide in the rat. Ann Agric Environ Med 2010;17(1):65-71, 66 ref.

15. Gronowska-Senger A, Burzykowska K, Przepiórka M. Retinyl palmitate and oxidative stress reduction in rats. Rocz Panstw Zakl Hig 2010;61(1):21-5, 31 ref. [in Polish].

16. Jakubowska A. Genes modifying breast and ovarian cancer risk. Ann Acad Med Stetin 2010;Suppl 142:150, 46 ref. [in Polish].

17. Jamioł-Milc D, Stachowska E, Chlubek D. Effects of dietary trans fatty acids in pregnancy and lactation. Ann Acad Med Stetin 2010;56(1):21-7, 87 ref. [in Polish]. 
18. Jankowska A, Czerczak S, Wągrowska-Koski E. Formamide. Documentation. Podst Met Oceny Srod Pr 2010;26(2):131-51, 55 ref. [in Polish].

19. Jankowska A, Czerczak S, Wagrowska-Koski E. N,N-Dimethylformamide. Documentation. Podst Met Oceny Srod Pr 2010;26(4):55-92, 66 ref. [in Polish].

20. Janosik E, Beluch K. Light and its regulating influence on human organism. Pr Zdrow Bezpiecz 2010;1: 1-5, 16 ref. [in Polish].

21. Jaworowska E. Clinical characteristics of laryngeal cancers in families with aggregation of malignant tumors. Ann Acad Med Stetin 2010;Suppl 141:1-37, 50 ref. [in Polish].

22. Karakis GP, Sin BA, Tutkak H, Kose K, Misirligil Z. Genetic aspect of venom allergy: association with HLA class I and class II antigens. Ann Agric Environ Med 2010;17(1):119-23, 24 ref.

23. Kolarzyk E, Szpanowska-Wohn A, Chrostek-Maj J. Zinc, copper and magnesium intake in a daily diet in opiate-addicted persons before and after 5 years of methadone treatment. Probl Hig Epidemiol 2010;91(2): 243-7, 19 ref.

24. Kostka G, Liszewska M, Urbanek-Olejnik K. Toxicogenomics in hazard assessment of chemicals. Rocz Panstw Zakl Hig 2010;61(2):119-27, 45 ref. [in Polish].

25. Kupczewska-Dobecka M, Wągrowska-Koski E. 2-Diethylaminoethanol. Documentation. Podst Met Oceny Srod Pr 2010;26(4):33-53, 47 ref. [in Polish].

26. Kwapuliński J, Ahnert B, Bogunia M, BrodziakDopierała B, Kowol J, Rochel R, et al. The influence of behavioural factors on the arsenic content in gallstones of inhabitants from Southern Poland. Med Srod 2010;13(2):18-24, 7 ref. [in Polish].

27. Kwapuliński J, Brodziak-Dopierała B, Kosterska E. The accumulation of nickel and chromium in the tissues of the femur head. Med Srod 2010;13(3):15-22, 19 ref. [in Polish].
28. Kwapuliński J, Brodziak-Dopierała B, Kowol J, Bogunia M, Ahnert B, Rochel R. The application criteria of osseous tissue of femur head as biomarker of risk by manganese. Med Srod 2010;13(2):11-7, 10 ref. [in Polish]. 29. Lis-Święty A, Brzezińska-Wcisło L, Bergler-Czop B, Meszyńska E. Skin reactions after use of antihistamines - A case of urticarial rash induced by loratadine. Przegl Dermatol 2010;97(4):268-72, 25 ref. [in Polish]. 30. Lutz P, Gralewicz S, Wiaderna D, Świercz R, Grzelińska Z, Majcherek W. Contrasting effects of 4-week inhalation exposure to pseudocumene or hemimellitene on sensitivity to amphetamine and propensity to amphetamine sensitization in the rat. Int J Occup Med Environ Health 2010;23(1):85-94, 38 ref. DOI: 10.2478/v10001-010-0005-8.

31. Łastawska K. Evaluation of selected food supplements containing antioxidants. Rocz Panstw Zakl Hig 2010;61(2):151-4, 7 ref.

32. Napora KJ, Obuchowska I, Mariak Z. Solar retinopathy as an example of photochemical retinal injury. Okulistyka 2010;4:73-5, 13 ref. [in Polish].

33. Pałaszewska-Tkacz A, Czerczak S, Wagrowska-Koski E. Benzyl butyl phthalate. Documentation. Podst Met Oceny Srod Pr 2010;26(3):27-60, 64 ref. [in Polish].

34. Pietraszkiewicz M, Ślęzak A. The mechanism and effects of cyanobacterial toxins on human organisms. Zdrow Publiczne 2010;120(1):87-92, 31 ref. [in Polish]. 35. Pilch W, Szyguła Z, Klimek AT, Pałka T, Cisoń T, Pilch $\mathrm{P}$, et al. Changes in the lipid profile of blood serum in women taking sauna baths of various duration. Int J Occup Med Environ Health 2010;23(2):16774, 33 ref. DOI: 10.2478/v10001-010-0020-9.

36. Politański P, Rajkowska E, Pawlaczyk-Łuszczyńska M, Dudarewicz A, Wiktorek-Smagur A, ŚliwińskaKowalska M, et al. Static magnetic field affects oxidative stress in mouse cochlea. Int J Occup Med Environ Health 2010;23(4):377-84, 18 ref. DOI: 10.2478/ v10001-010-0041-4. 
37. Postrzech K, Welz K, Kopyra J, Reich A. Evaluation of the impact of ultraviolet $B$ radiation on the epidermal barrier. Przegl Dermatol 2010;97(3):185-90, 20 ref. [in Polish].

38. Rejdak R, Choragiewicz T, Stopa P, Lewicka-Chomont A, Haszcz D, Nowomiejska K, et al. Perspectives for neuroprotection in optic nerve neuropathies. Okulistyka 2010;2:75-81, 69 ref. [in Polish].

39. Rejdak R, Choragiewicz T, Stopa P, Lewicka-Chomont A, Haszcz D, Nowomiejska K, et al. New aspects of neurodegeneration and neuroprotection of the retinal ganglion cells and visual pathway - role of the tryptophan derivatives. Okulistyka 2010;2:82-6, 45 ref. [in Polish].

40. Rejdak R, Oleszczuk A, Mańkowska A, Kiczyńska M, Zagórski Z,Żarnowski T. Novelty of vital dyes in ophthalmic surgery. Klin Oczna 2010;112(4-6): 151-5, 18 ref. [in Polish].

41. Rudziński R. Effect of tobacco smoking on the course and degree of advancement inflammation in periodontal tissue. Ann Acad Med Stetin 2010;56(2):97-105, 73 ref. [in Polish].

42. Rylander R. Organic dust induced pulmonary disease the role of mould derived $\beta$-glucan. Ann Agric Environ Med 2010;17(1):9-13, 42 ref.

43. Sałacka A, Kozielec T, Karakiewicz B. Cadmium and zinc concentrations in the hair after of adults magnesium supplementation. Med Srod 2010;13(1):60-4, 21 ref. [in Polish].

44. Sałata-Nowak J, Flisiak I, Chodynicka B. Effect of tobacco smoking on the skin. Przegl Dermatol 2010;97(5):342-8, 79 ref. [in Polish].

45. Sapota A, Skrzypińska-Gawrysiak M, WągrowskaKoski E. Mercury. Documentation. Podst Met Oceny Srod Pr 2010;26(3):85-149, 193 ref. [in Polish].

46. Sawicka E, Długosz A, Średnicka D. The combined effect of Scutellaria baicalensis extract and coenzyme Q10 in oxidative stress induced by chromium compounds. Med Srod 2010;13(1):72-7, 20 ref. [in Polish].
47. Semczuk-Sikora A, Czuczwar S, Semczuk A, Kwaśniewska A, Semczuk M. Valproic acid transfer across human placental cotyledon during dual perfusion in vitro. Ann Agric Environ Med 2010;17(1): 153-7, 38 ref.

48. Siemińska A. Searching for genes influencing tobacco smoking susceptibility. Pneumonol Alergol Pol 2010;78(6):432-8, 57 ref. [in Polish].

49. Sitarek K, Szymczak W, Wagrowska-Koski E. Epoxyethane. Documentation. Podst Met Oceny Srod Pr 2010;26(2):79-107, 79 ref. [in Polish].

50. Sitarek K, Wągrowska-Koski E. 1,6-Hexamethylene diisocyanate (HDI). Documentation. Podst Met Oceny Srod Pr 2010;26(2):31-45, 22 ref. [in Polish].

51. Sitarek K, Wąsowicz W, Wągrowska-Koski E. 1,4-Phenylenediamine. Documentation. Podst Met Oceny Srod Pr 2010;26(3):5-25, 47 ref. [in Polish].

52. Skotarczak B. Progress in the molecular methods for the detection and genetic characterization of Cryptosporidium in water samples. Ann Agric Environ Med 2010;17(1):1-8, 65 ref.

53. Soćko R, Czerczak S, Wagrowska-Koski E. Toluene-2,4 or 2,6-diisocyanate and the mixture of TDI isomers. Documentation. Podst Met Oceny Srod Pr 2010;26(2): 47-77, 97 ref. [in Polish].

54. Soćko R, Czerczak S, Wągrowska-Koski E. Ethyl benzene. Documentation. Podst Met Oceny Srod Pr 2010;26(2):109-30, 55 ref. [in Polish].

55. Stafiej J, Kaźmierczak K, Malukiewicz G. Toxic optic neuropathy after chemotherapy - Case report. Okulistyka 2010;2:105-7, 14 ref. [in Polish].

56. Starek A, Szymczak W, Wagrowska-Koski E. 2-Chlorobuta-1,3-dien. Documentation. Podst Met Oceny Srod Pr 2010;26(4):5-32, 46 ref. [in Polish].

57. Szymańska JA, Bruchajzer E, Wągrowska-Koski E. Elemental iodine. Documentation. Podst Met Oceny Srod Pr 2010;26(3):61-83, 61 ref. [in Polish]. 
58. Szymańska JA, Bruchajzer E, Wągrowska-Koski E. 2-Methoxyethanol. Documentation. Podst Met Oceny Srod Pr 2010;26(4):93-139, 112 ref. [in Polish].

59. Szymańska JA, Frydrych B, Wagrowska-Koski E. 2-Methoxyethyl acetate. Documentation. Podst Met Oceny Srod Pr 2010;26(4):141-58, 37 ref. [in Polish].

60. Świdwińska-Gajewska A, Kupczewska-Dobecka M, Wagrowska-Koski E. 1-Bromopropane. Documentation. Podst Met Oceny Srod Pr 2010;26(2):5-29, 43 ref. [in Polish].

61. Świercz R, Wąsowicz W, Majcherek W. The toxicokinetics of 2-methylnaphtalene in rats. Int J Occup Med Environ Health 2010;23(4):385-9, 11 ref. DOI: 10.2478/ v10001-010-0026-3.

62. Tarkowski M, Kur B, Nocuń M, Sitarek K. Perinatal exposure of mice to $T C D D$ decreases allergic sensitisation through inhibition of IL-4 production rather than T regulatory cell-mediated suppression. Int J Occup Med Environ Health 2010;23(1):75-83, 39 ref. DOI: 10.2478/ v.10001-010-0006-7.

63. Wawrzyniak A, Hamułka J, Pankowska I. Evaluation of nitrites and nitrates food intake in the students' group. Rocz Panstw Zakl Hig 2010;61(4):367-72, 8 ref. [in Polish].

64. Wolska A, Głogowski P. Laser radiation. Documentation of admissible values of the intensity of the physical factor. Podst Met Oceny Srod Pr 2010;26(1):578, 23 ref. [in Polish].

65. Zielińska-Bliźniewska H, Miłoński J, Olszewski J. The case of a sudden hearing loss in a patient treated for hepatitis $C$ with peginterferon $\alpha$-2b. Lek Wojsk 2010;88(3):275-8, 10 ref. [in Polish].

\section{OCCUPATIONAL PATHOLOGY}

1. Akdur O, Ozkan S, Durukan P, Avsarogullari L, Koyuncu M, Ikizceli I. Machine-related farm injuries in Turkey. Ann Agric Environ Med 2010;17(1):59-63, 25 ref.
2. Bortkiewicz A, Gadzicka E, Siedlecka J, Szyjkowska A, Viebig P, Wranicz JK, et al. Work-related risk factors of myocardial infarction. Int J Occup Med Environ Health 2010;23(3):255-65, 41 ref. DOI: 10.2478/ v10001-010-0030-7.

3. Braczkowska B, Kowalska M, Beniowski M, Zejda JE, Mazur W, Witor A. Occupational exposure to HIV in health care workers, Silesia voivodeship. Med Pr 2010;61(3):315-22, 18 ref. [in Polish].

4. Buczyńska A, Szadkowska-Stańczyk I. Occupational hygiene and health hazards related to concentrated animal feeding operations (CAFOs). Med Pr 2010;61(3):32331, 40 ref. [in Polish].

5. Bujak-Pietrek S. Occupational exposure to nanoparticles. Assessment of workplace exposure. Med Pr 2010;61(2):183-9, 33 ref. [in Polish].

6. Chmielewska-Badora J, Cisak E, Zając V, Zwoliński J, Dutkiewicz J. Occurrence of coinfections with Borrelia burgdorferi, Anaplasma phagocytophilum, Bartonella spp. and Babesia microti in patients diagnosed with borreliosis. Med Ogolna 2010;16(2):217-25, 10 ref. [in Polish].

7. Chomiczewska D, Kieć-Świerczyńska M, Kręcisz B. Irritant contact dermatitis. Part III. Non-invasive methods to assess biophysical properties of the skin. Med Pr 2010;61(4):457-66, 58 ref. [in Polish].

8. Feltzke M, Perz K, Miśkowiak B. Self-evaluation of vision process and results of visual acuity examinations in students of Nursing, Faculty of Health Sciences at Poznan University of Medical Sciences. Probl Hig Epidemiol 2010;91(2):280-4, 13 ref. [in Polish].

9. Garbacewicz A, Udziela M, Grytner-Zięcina B, Szaflik JP, Szaflik J. Demodex infections in general Polish population, in patients suffering from blepharitis, and among people who work with microscopes. Klin Oczna 2010;112(10-12):307-10, 14 ref.

10. Gać P, Pawlas K. Work-related exposure to cytostatics. Bezpiecz Pr 2010;(9):18-21, 14 ref. [in Polish]. 
11. Goljan J, Myjak P, Nahorski W, Kubica-Biernat B, Felczak-Korzybska I, Kowalczyk D, et al. Dengue antibodies in Polish travellers returning from the tropics. Evaluation of serological tests. Int Marit Health 2010;61(1): 36-40, 18 ref.

12. Górski P. Ability to localize sound sources by people with a hearing dysfunction. Bezpiecz Pr 2010;7-8: 35-7, 11 ref. [in Polish].

13. Hanus-Atras K, Iłżecka J. Back pain - causes and procedure. Med Ogolna 2010;16(3):315-22, 14 ref. [in Polish].

14. Heldal KK, Madso L, Huser PO, Eduard W. Exposure, symptoms and airway inflammation among sewage workers. Ann Agric Environ Med 2010;17(2):263-8, 33 ref.

15. Janasik B, Jakubowski M, Wesołowski W, Kucharska M. Unmetabolized VOCs in urine as biomarkers of low level occupational exposure. Int J Occup Med Environ Health 2010;23(1):21-6, 18 ref. DOI: 10.2478/ v10001-010-0003-x.

16. Kieć-Świerczyńska M, Chomiczewska D, Kręcisz B. Wet work. Med Pr 2010;61(1):65-77, 86 ref. [in Polish]. 17. Knap JP, Nowakowska A, Dutkiewicz J, Zając V, Wójcik-Fatla A, Chmielewska-Badora J, et al. Detection of antibodies against hantaviruses in forestry workers of the Roztocze National Park and Pulawy Forest Inspectorate (Lublin Macroregion). Preliminary report. Med Ogolna 2010;16(2):201-16, 28 ref. [in Polish].

18. Kowalska M, Zajusz-Zubek E. Occupational exposure to ozone in workers using photocopiers and printers. Med Pr 2010;61(5):549-51, 10 ref. [in Polish].

19. Krasuski M, Tederko P. Imaging in the diagnostics of low back pain. Med Ogolna 2010;16(2):117-30, 40 ref. [in Polish].

20. Krawczyk P, Białkowska J, Dworniak D, Kamerys J, Szosland D, Jabłkowski M. Is healthcare personnel the only professional group exposed to the risk of occupational HBV, HCV or HIV infections? Med Pr 2010;61(1): 15-23, 18 ref. [in Polish].

21. Krzesiński P, Gielerak G. Cardiovascular risk in soldiers with hypertension. Range of acceptable extrapolation of risk in the general population. Lek Wojsk 2010;88(3):227-34, 15 ref. [in Polish].

22. Krzywański J. Nitrous oxide impact on the human health. Pr Zdrow Bezpiecz 2010;3-4:18-21, 31 ref. [in Polish]. 23. Kuczma-Napierała J, Bresińska A, Duszyński M. Characteristics of occupational risk for workers with a agriculture farm including biological agents, plant protection and biocidal products. Probl Hig Epidemiol 2010;91(2):318-22, 2 ref. [in Polish].

24. Kupper TE, Zimmer B, Conrad G, Jansing P, Hardt A. Noise exposure during ambulance flights and repatriation operations. Int J Occup Med Environ Health 2010;23(4):323-9, 25 ref. DOI: 10.2478/v10001010-0036-1.

25. Kułagowska E, Kosińska M. Working conditions of community nurses. Med Pr 2010;61(6):641-7, 12 ref. [in Polish].

26. Leedom Larson KR, Smith TC, Donham KJ. Selfreported methicillin-resistant Staphylococcus aureus infection in USA pork producers. Ann Agric Environ Med 2010;17(2):331-4, 17 ref.

27. Lucas D, Lucas R, Boniface K, Jegaden D, Lodde B, Dewitte JA. Occupational asthma in the commercial fishing industry: a case series and review of the literature. Int Marit Health 2010;61(1):13-7, 45 ref.

28. Marcinkiewicz A, Szosland D. Selected risk factors of diabetes mellitus among road transport drivers. Int J Occup Med Environ Health 2010;23(2):175-80, 19 ref. DOI: 10.2478/v10001-010-0018-3.

29. Marszałek S, Niebudek-Bogusz E, Woźnicka E, Śliwińska-Kowalska M. The application of physiotherapeutic and ostheopatic diagnostics in occupational voice disorders. Med Pr 2010;61(2):205-11, 30 ref. [in Polish].

30. Matuszewski K, Kalus A. Incidence rate of pneumoconiosis in coal mining and the efficiency of preventive measures. Bezpiecz Pr 2010;2:13-6, 7 ref. [in Polish]. 
31. Mikulska D. Raynaud's phenomenon: pathogenesis and prevalence. Ann Acad Med Stetin 2010;56(1): 11-4, 30 ref. [in Polish].

32. Munch JS, Johnsen BH, Birkeland I, Finne M, Utkilen T, Boe T, et al. A study of the side effects of Pandemrix ${ }^{\circledR}$ influenza (H1N1) vaccine after whole-crew vaccination on board a Norvegian naval vessel. Int Marit Health 2010;61(4):246-50, 11 ref.

33. Niebudek-Bogusz E, Marszałek S, Woźnicka E, Minkiewicz Z, Hima J, Śliwińska-Kowalska M. Extensive treatment of teacher's voice disorders in health spa. Med Pr 2010;61(6):685-91, 28 ref. [in Polish].

34. Niebudek-Bogusz E, Woźnicka E, ŚliwińskaKowalska M. Applicability of the Vocal Tract Discomfort (VTD) scale in the diagnostics of functional dysphonia. Otorynolaryngologia 2010;9(4):204-9, 28 ref. [in Polish].

35. Norum J. Cardiovascular disease (CVD) in the Norwegian Arctic. Air ambulance operations 19992009 and future challenges in the region. Int Marit Health 2010;61(3):117-22, 12 ref.

36. Novakova M, Vichova B, Majlathova V, Lesnakova A, Pochybova M, Petko B. First case of human granulocytic anaplasmosis from Slovakia. Ann Agric Environ Med 2010;17(1):173-5, 12 ref.

37. Oldenburg M, Baur X, Schlaich C. Cardiovascular diseases in the modern maritime industry. Int Marit Health 2010;61(3):101-6, 24 ref.

38. Olewińska E, Kasperczyk A, Kapka L, Kozłowska A, Pawlas N, Dobrakowski M, et al. Level of DNA damage in lead-exposed workers. Ann Agric Environ Med 2010;17(2):231-6, 35 ref.

39. Ondriska F, Lengyel D, Miterpakova M, Lengyelova B, Streharova A, Dubinsky P. Human dirofilariosis in the Slovak Republic - A case report. Ann Agric Environ Med 2010;17(1):169-71, 19 ref.

40. Pastuszka JS, Losa A. Incidents of sick building syndrome among office workers in selected cities in Silesia Province. Pr Zdrow Bezpiecz 2010;2:11-5, 16 ref. [in Polish].
41. Pawlaczyk-Łuszczyńska M, Dudarewicz A, Zamojska M, Śliwińska-Kowalska M. Risk assessment of hearing loss in orchestral musicians. Med Pr 2010;61(5):493511, 32 ref. [in Polish].

42. Pawlas N, Olewińska E, Kozłowska A, Pawlas K. Impact of genetic polymorphisms and gene-environment interactions assessing health effects of environmental and occupational exposure to lead. Med Srod 2010;13(4):7580, 39 ref. [in Polish].

43. Perz K, Feltzke M, Miśkowiak B, Gierszal H. Binocular vision and vision quality in students of Nursing Faculty at Poznań University of Medical Sciences. Probl Hig Epidemiol 2010;91(2):285-90, 13 ref. [in Polish].

44. Piesiaków ML, Imko-Walczuk B, Jaśkiewicz J. Strongyloidiasis - Case report and literature review. Przegl Dermatol 2010;97(4):273-80, 28 ref. [in Polish].

45. Poręba R, Gać P, Poręba M, Derkacz A, Pilecki W, Antonowicz-Juchniewicz J, et al. Relationship between chronic exposure to lead, cadmium and manganese, blood pressure values and incidence of arterial hypertension. Med Pr 2010;61(1):5-14, 23 ref. [in Polish].

46. Pougnet R, Lodde B, Lucas D, Jegaden D, Bell S, Dewitte JD. A case of occupational asthma from metabisulphite in a fisherman. Int Marit Health 2010;61(3): 180-4, 15 ref.

47. Rogowska-Szadkowska D, Stanisławowicz M, Chlabicz S. Risk of needle stick injuries in health care workers: bad habits (recapping needles) last long. Przegl Epidemiol 2010;64(2):293-5, 9 ref.

48. Schepers BF, Dahl E. Seafarer with solitary, well-functioning kidney - fit for service at sea without restrictions? Int Marit Health 2010;61(3):185-7, 17 ref.

49. Siennicka J, Trzcińska A, Gut W. Immunity against tick borne encephalitis virus (TBE) in population of forest workers in Bialowieza. Przegl Epidemiol 2010;64(2):303-5, 10 ref. [in Polish].

50. Sińczuk-Walczak H, Szymczak M, Hałatek T. Effects of occupational exposure to arsenic on the nervous 
system: clinical and neurophysiological studies. Int J Occup Med Environ Health 2010;23(4):347-55, 20 ref. DOI: 10.2478/v10001-010-0034-3.

51. Skibińska A, Łagocka A, Kruszewski J. Cyanoacrylate glue accidentally applied into the conjunctival sac: A case report. Lek Wojsk 2010;88(3):283-5, 5 ref. [in Polish].

52. Skoczyńska A, Jędrejko M, Martynowicz H, Poręba R, Affelska-Jercha A, Steinmetz-Beck A, et al. The cardiovascular risk in chemical factory workers exposed to mercury vapor. Med Pr 2010;61(4):381-91, 28 ref. [in Polish].

53. Sroka J, Wójcik-Fatla A, Szymańska J, Dutkiewicz J, Zając V, Zwoliński J. The occurrence of Toxoplasma gondii infection in people and animals from rural environment of Lublin region - estimate of potential role of water as a source of infection. Ann Agric Environ Med 2010;17(1):125-32, 37 ref.

54. Szadkowska-Stańczyk I, Bródka K, Buczyńska A, Cyprowski M, Kozajda A, Sowiak M. Exposure to bioaerosols among CAFO workers (swine feeding). Med Pr 2010;61(3):257-69, 49 ref. [in Polish].

55. Szewczyńska M, Dobrzyńska E, Pośniak M. Cleaners' exposure to chemical hazards. Bezpiecz Pr 2010;(2): 7-9, 15 ref. [in Polish].

56. Świderska-Kiełbik S, Krakowiak A, Wiszniewska M, Dudek W, Walusiak-Skorupa J, Krawczyk-Szulc P, et al. Health hazards associated with occupational exposure to birds. Med Pr 2010;61(2):213-22, 54 ref. [in Polish].

57. Świątkowska B. The most common occupational pathologies in Poland and methods of their prevention. Med Pr 2010;61(6):661-9, 33 ref. [in Polish].

58. Talebi-Taher M, Noori M, Shamshiri AR, Barati M. Varicella zoster antibodies among health care workers in a University Hospital, Teheran, Iran. Int J Occup Med Environ Health 2010;23(1):27-32, 34 ref. DOI: 10.2478/v10001-010-0011-X.

59. Tatara T, Dąbrowska-Bender M. The most common illnesses caused by office work. Zdrow Publiczne 2010;120(2):203-8, 13 ref. [in Polish].
60. Turczyn B, Skoczyńska A, Wojakowska A. Serum and urinary glycosaminoglycans in workers chronically exposed to lead. Med Pr 2010;61(5):553-60, 20 ref. [in Polish].

61. Valle B, Camelot D, Bounes V, Parant M, Battefort F, Ducasse JL, et al. Cardiovascular diseases and electrocardiogram teletransmission aboard ships: the French TMAS experience. Int Marit Health 2010;61(3): 129-36, 24 ref.

62. Wagrowska-Koski E, Rybacki M. Identification of the most common problems and mistakes in the medical certification of inability to work for disability pension provision based on the expertise carried out by the outpatient Clinic of Occupational Diseases, Nofer Institute of Occupational Medicine, Łódź 2005-2007. Med Pr 2010;61(1):23-33, 20 ref. [in Polish].

63. Welc-Falęciak R, Hildebrandt A, Siński E. Co-infection with Borrelia species and other tick-borne pathogens in humans: two cases from Poland. Ann Agric Environ Med 2010;17(2):309-13, 45 ref.

64. Wiszniewska M, Świerczyńska-Machura D, Pałczyński C, Walusiak-Skorupa J. Fungal allergy among art conservators: prevalence, risk factors and clinical symptoms. Med Pr 2010;61(2):133-41, 18 ref. [in Polish].

65. Wolańczyk-Medrala A, Barg W, Radlińska A, Panaszek B, Medrala W. Food-dependent exercise-induced anaphylaxis-sequence of causative factors might be reversed. Ann Agric Environ Med 2010;17(2): 315-7, 15 ref.

66. Wolańska-Klimkiewicz E, Szymańska J, Bachanek T. Orofacial symptoms related to borreliosis - Case report. Ann Agric Environ Med 2010;17(2):319-21, 16 ref.

67. Wolska A, Gałecki Ł. Occupational exposure to solar ultraviolet radiation in Poland - Estimation. Bezpiecz Pr 2010;1:14-7, 11 ref. [in Polish].

68. Zagórski J. Obstacles in diagnosing and confirmation of occupational diseases in private farming in Poland. Ann Agric Environ Med 2010;17(1):177-9, 14 ref. 
69. Zarzoso M, Llana S, Perez-Soriano P. Potential negative effects of chlorinated swimming pool attendance on health of swimmers and associated staff. Biol Sport 2010;27(4):233-40, 80 ref.

70. Zgorzelska-Kowalik J, Wiszniewska M, Kowalik D, Krawczyk-Szulc P, Nowakowska-Świrta E, Pałczyński $\mathrm{C}$, et al. Cross-reactive carbohydrate determinants in diagnostics of occupational allergy. Med Pr 2010;61(1): 79-89, 64 ref. [in Polish].

71. Zieliński J, Bednarek M, Górecka D. Active detection of COPD in Poland in the second decade of XXI century. Pneumonol Alergol Pol 2010;78(4):251-5, 20 ref. [in Polish].

72. Ziewska B, Marcinkowski JT. Health status of the employees of the Poznan University of Medical Sciences. Probl Hig Epidemiol 2010;91(1):54-6, 4 ref. [in Polish].

\section{EPIDEMIOLOGICAL STUDIES}

1. Aldrich TE, Seidu D, Bahr D, Freitas S, Brion GM, Tollerud D. Time-period mortality patterns in a gaseous diffusion plant workforce. Int J Occup Med Environ Health 2010;23(2):145-51, 25 ref. DOI: 10.2478/v10001010-0022-7.

2. Alves PM, Leigh R, Bartos G, Mody R, Gholson L, Nerwich N. Cardiovascular events on board commercial maritime vessels: $A$ two-year review. Int Marit Health 2010;61(3):137-42, 25 ref.

3. Amarasekera M, Rathnamalala N, Samaraweera S, Jinadasa M. Prevalence of latex allergy among healthcare workers. Int J Occup Med Environ Health 2010;23(4):391-6, 18 ref. DOI: 10.2478/v10001010-0040-5.

4. Baumann A. Hepatitis A in Poland in 2008. Przegl Epidemiol 2010;64(2):235-7 [in Polish].

5. Baumann A, Sadkowska-Todys M. Foodborne infections and intoxications in Poland in 2008. Przegl Epidemiol 2010;64(2):205-12 [in Polish].
6. Bojar I, Szymańska J. Environmental exposure of pregnant women to infection with Toxoplasma gondii state of the art. Ann Agric Environ Med 2010;17(2): 209-14, 55 ref.

7. Borysławski K, Pawłowska A. The longitudinal study of selected health indicators among gas company workers in Wroctaw. Med Pr 2010;61(4):419-29, 32 ref. [in Polish].

8. Choi B, Schnall PL, Yang H, Dobson M, Landsbergis P, Israel L, et al. Psychosocial working conditions and active leisure-time physical activity in middle-aged US workers. Int J Occup Med Environ Health 2010;23(3): 239-53, 52 ref. DOI: 10.2478/v10001-010-0029-0.

9. Cholewińska G, Higersberger J, Podlasin R, WiercińskaDrapało A, Lipowski D, Olszyńska-Krowicka M, et al. Clinical manifestations, diagnosis and treatment of swine flu (A/H1N1) infection among patients hospitalized in the Hospital of Infectious Diseases in Warsaw in 2009. Przegl Epidemiol 2010;64(1):15-9, 15 ref. [in Polish].

10. Cholewińska G, Higersberger J, Podlasin R, Wiercińska-Drapało A, Lipowski D, OlszyńskaKrowicka M, et al. Influence of concomitant illness on clinical manifestations and severity of A/H1N1 influenza infection among patients hospitalized in the Hospital of Infectious Diseases in Warsaw - Clinical cases. Przegl Epidemiol 2010;64(1):21-5, 10 ref. [in Polish].

11. Czeczelewska E, Karczewski JK. Incidence of neoplasms in the population inhabiting the northern part of the Lubelskie Province between 1999-2006. Probl Hig Epidemiol 2010;91(1):87-91, 14 ref. [in Polish].

12. El-Helaly M, Awadalla N, Mansour M, El-Biomy Y. Workplace exposures and male infertility - A case-control study. Int J Occup Med Environ Health 2010;23(4):331-8, 47 ref. DOI: 10.2478/v10001010-0039-y.

13. Frąckiewicz J, Roszkowski W, Brzozowska A, Kałuża J. Diet quality and mortality in elderly people living in Warsaw region. Przegl Epidemiol 2010;64(1): 119-25, 17 ref. [in Polish]. 
14. Gańczak M. Analysis of selected risk factors for occupational HBV, HCV and HIV infections among medical staff with a focus on nurses working within surgical and emergency departments. Ann Acad Med Stetin 2010; Suppl 144:1-98, 197 ref. [in Polish].

15. Gładysz J, Grzesiak A, Nieradko-Iwanicka B, Borzęcki A. The influence of air pollution on human health and life expectancy. Probl Hig Epidemiol 2010;91(2):178-80, 12 ref. [in Polish].

16. Grabowska-Fudala B, Jaracz K, Górna K. Stroke incidence, case fatality and mortality - current trends and future prognosis. Przegl Epidemiol 2010;64(3): 439-42, 29 ref. [in Polish].

17. Guevara N, Pineda M, Dorotan M, Ghimire K, Co M, Guzman A, et al. Cross-sectional survey on the knowledge, attitude, and practices of male Filipino seafarers regarding sexual health. Int Marit Health 2010;61(4): 224-32, 11 ref.

18. Holmberg SAC, Thelin AG. Predictors of sick leave owing to neck or low back pain: a 12-year longitudinal cohort study in a rural male population. Ann Agric Environ Med 2010;17(2):251-7, 34 ref.

19. Jacobsen G, Schaumburg I, Sigsgaard T, Schlunssen V. Non-malignant respiratory diseases and occupational exposure to wood dust. Part I. Fresh wood and mixed wood industry. Ann Agric Environ Med 2010;17(1): 15-28, 66 ref.

20. Jacobsen G, Schaumburg I, Sigsgaard T, Schlunssen V. Non-malignant respiratory diseases and occupational exposure to wood dust. Part II. Dry wood industry. Ann Agric Environ Med 2010;17(1):29-44, 74 ref.

21. Jagodziński J, Zielonka TM. Immigrants treated for tuberculosis in Mazovian Center for Treatment of Lung Diseases and Tuberculosis in Otwock. Pneumonol Alergol Pol 2010;78(6):399-406, 33 ref. [in Polish].

22. Januszewski J. Multiple body injuries in the data files of Emergency Actions of Specialist (ALS) teams. Zdrow Publiczne 2010;120(3):271-7, 19 ref.
23. Jokiel M, Bielska-Lasota M. Breast cancer risk factors - possibilities of primary prevention. Przegl Epidemiol 2010;64(3):435-8, 20 ref. [in Polish].

24. Karasek R, Collins S, Clays E, Bortkiewicz A, Ferrario M. Description of a large-scale study design to assess work-stress-disease associations for cardiovascular disease. Int J Occup Med Environ Health 2010;23(3): 293-312, 56 ref. DOI: 10.2478/v10001-010-0035-2.

25. Kasznia-Kocot J, Kowalska M, Górny RL, Niesler A, Wypych-Ślusarska A. Environmental risk factors for respiratory symptoms and childhood asthma. Ann Agric Environ Med 2010;17(2):221-9, 53 ref.

26. Kłapeć T, Stroczyńska-Sikorska M. Tetanus - a disease still occurring in Poland. Med Ogolna 2010;16(3): 3406, 8 ref. [in Polish].

27. Kłosiewicz-Latoszek L. Obesity as a social, medical and therapeutic problem. Probl Hig Epidemiol 2010;91(3):339-43, 36 ref. [in Polish].

28. Korzeniewska-Koseła M. Tuberculosis in Poland in 2008. Przegl Epidemiol 2010;64(2):275-9 [in Polish].

29. Korzeniewski K, Kacprzak E. Diarrheal diseases among soldiers participating in contemporary military operations. Lek Wojsk 2010;88(2):172-5, 38 ref. [in Polish].

30. Kołodziej H, Łopuszańska M. Regional differences in premature mortality in Poland. Przegl Epidemiol 2010;64(4):543-50, 31 ref. [in Polish].

31. Krzyżak M, Maślach D, Bielska-Lasota M, Juczewska M, Rabczenko D, Marcinkowski JT, et al. Breast cancer survival gap between urban and rural female population in Podlaskie voivodship, Poland, in 2001-2002. Population study. Ann Agric Environ Med 2010;17(2):277-82, 34 ref.

32. Krzyżak M, Maślach D, Juczewska M, Lasota W, Rabczenko D, Marcinkowski JT, et al. Differences in breast cancer incidence and stage distribution between urban and rural female population in Podlaskie voivodship, Poland in years 2001-2002. Ann Agric Environ Med 2010;17(1):159-62, 24 ref. 
33. Kupryś-Lipińska I, Elgalal A, Kuna P. The underdiagnosis and undertreatment of asthma in general population of the Lodz Province (Poland). Pneumonol Alergol Pol 2010;78(1):21-7, 23 ref. [in Polish].

34. Lucas R, Boniface K, Hite M. Skin disorders at sea. Int Marit Health 2010;61(1):9-12, 13 ref.

35. Mach P, Zielińska-Danch W, Goniewicz MŁ, Koszowski B, Czogała J, Sobczak A. Waterpipe smoking among adolescents as a new unsurveyed worldwide phenomenon. Probl Hig Epidemiol 2010;91(3): 357-63, 24 ref. [in Polish].

36. Mackiewicz J, Dolar-Szczasny J, Bieliński P. Agerelated macular degeneration (AMD) - epidemiology of the 21st century. Zdrow Publiczne 2010;120(4): 400-3, 15 ref.

37. Mazur J. Regression-based methods in the studies on health inequalities. Probl Hig Epidemiol 2010;91(1): 21-7, 27 ref. [in Polish].

38. Mlekodaj S, Krasucki P. Mortality rates in Poland in the years 1995-2006. Zdrow Publiczne 2010;120(3):292-4 [in Polish].

39. Mulić R, Vidan P, Poljak NK. HIV infection among seafarers in Croatia. Int Marit Health 2010;61(4): 209-14, 21 ref.

40. Napieralska E, Kułaga Z, Gurzkowska B, Grajda A. Epidemiology of children and adolescent suicides in Poland in 1999-2006. Probl Hig Epidemiol 2010;91(1): 92-8, 22 ref. [in Polish].

41. Napiórkowska A, Sadkowska-Todys M. Epidemiological situation of human norovirus infections in Poland during 2004-2008. Przegl Epidemiol 2010;64(1): 27-33, 24 ref. [in Polish].

42. Napiórkowska A, Sadkowska-Todys M. Yersiniosis in Poland in 2008. Przegl Epidemiol 2010;64(2):213-6 [in Polish].

43. Netterstrom B, Kristensen TS, Jensen G, Schnor P. Is the demand-control model still a usefull tool to assess work-related psychosocial risk for ischemic heart disease? Results from 14 year follow up in the Copenhagen City Heart study. Int J Occup Med Environ Health 2010;23(3):217-24, 27 ref. DOI: 10.2478/ v10001-010-0031-6.

44. Nowacki Z, Neuberg J, Strzałka K, Szczepanik M, Szczepanik R, Mazurek H. Is prediction of the allergic march possible on the basis of nasal cytology? Pneumonol Alergol Pol 2010;78(4):263-70, 30 ref. [in Polish].

45. Nowak J, Pacholczyk A, Petroniec V, Dziedzicka B, Zwolska Z. The results of molecular epidemiological investigations in patients infected with strains of the genus Acinetobacter. Pneumonol Alergol Pol 2010;78(6):38691, 21 ref. [in Polish].

46. Oldenburg M, Jensen HJ, Latza U, Baur X. The risk of coronary heart disease of seafarers on vessels sailing under German flag. Int Marit Health 2010;61(3): 123-8, 22 ref.

47. Patil RR. Investigating genetic outcomes following 1984 Toxic Union Carbide disaster in India: epidemiological challenges [letter to the editor]. Int J Occup Med Environ Health 2010;23(4):397-8, 3 ref. DOI: 10.2478/ v10001-010-0025-4.

48. Piecewicz-Szczęsna H, Karwat ID. Demographic and health issues in the Polish population versus types of tasks regarding health education. Zdrow Publiczne 2010;120(3):295-9, 12 ref. [in Polish].

49. Polakowska M, Piotrowski W. Socioeconomic factors and prevalence of arterial hypertension in rural and urban areas. WOBASZ study. Med Ogolna 2010;16(2): 162-73, 24 ref. [in Polish].

50. Polańska K, Hanke W, Sobala W, Brzeźnicki S, Ligoc$\mathrm{ka}$ D. Exposure to polycyclic aromatic hydrocarbons and newborn biometric indicators. Int J Occup Med Environ Health 2010;23(4):339-46, 19 ref. DOI: 10.2478/ v10001-010-0028-1.

51. Roberts SE, Jaremin B. Cardiovascular disease mortality in British merchant shipping and among British seafarers ashore in Britain. Int Marit Health 2010;61(3): 107-16, 35 ref. 
52. Roberts SE, Jaremin B, Marlow PB. Human and fishing vessel losses in sea accidents in the UK fishing industry from 1948 to 2008. Int Marit Health 2010;61(3): 143-53, 41 ref.

53. Romanowska M, Czarkowski MP, Nowak I, Staszewska E, Donevski S, Brydak LB. Influenza in Poland in 2008. Przegl Epidemiol 2010;64(2):175-9 [in Polish].

54. Saniel OP, De Ios Reyes SJ. Prevalence of risky behaviours and determinants of multiple sex partnerships among male Filipino seafarers. Int Marit Health 2010;61(4):215-23, 21 ref.

55. Schlaich C, Riemer T, Lamshoft M, Hagelstein JG, Oldenburg M. Public health significance of chickenpox on ships - conclusions drawn from a case series in the port of Hamburg. Int Marit Health 2010;61(1): 28-31, 10 ref.

56. Sergeev AV, Carpenter DO. Residential proximity to environmental sources of persistent organic pollutants and first-time hospitalizations for myocardial infarction with comorbid diabetes mellitus: a 12-year population-based study. Int J Occup Med Environ Health 2010;23(1): 5-13, 47 ref. DOI: 10.2478/v10001-010-0010-y.

57. Siatkowska H, Kozielski J, Ziora D. Chronic obstructive pulmonary disease patients in the general practice. Pneumonol Alergol Pol 2010;78(2):112-20, 46 ref. [in Polish].

58. Siegrist J. Effort-reward imbalance at work and cardiovascular diseases. Int $\mathrm{J}$ Occup Med Environ Health 2010;23(3):279-85, 47 ref. DOI: 10.2478/ v10001-010-0013-8.

59. Simon K, Simon R, Serafińska S. HIVIAIDS and aging. Przegl Epidemiol 2010;64(2):287-92, 28 ref.

60. Sitarz R, Kolasińska-Bzoma M, Polkowski W, Offerhaus J, Maciejewski R. Gastric cancer - topical problem. Zdrow Publiczne 2010;120(3):311-5, 55 ref. [in Polish].

61. Skrodeniene E, Marciulionyte D, Padaiga Ż, Jasinskiene E, Sadauskaite-Kuehne V, Sanjeevi CB, et al.
Associations between HLA class II haplotypes, environmental factors and type 1 diabetes mellitus in Lithuanian children with type 1 diabetes and controls. Pol Ann Med 2010;17(1):7-15, 30 ref.

62. Stępień M. Malaria in Poland in 2008. Przegl Epidemiol 2010;64(2):273-4 [in Polish].

63. Stępień M, Czarkowski MP. Hepatitis $B$ in Poland in 2008. Przegl Epidemiol 2010;64(2):239-44 [in Polish].

64. Stępień M, Rosińska M. Hepatitis C in Poland in 2008. Przegl Epidemiol 2010;64(2):245-5 [in Polish].

65. Stęplewski Z. Children's lead poisoning in the industrial Upper Silesian Region of Poland. Zdrow Publiczne 2010;120(1):14-8, 21 ref.

66. Stypułkowska-Misiurewicz H, Napiórkowska A. Legionellosis in Poland in 2008. Przegl Epidemiol 2010;64(2):195-7 [in Polish].

67. Szukalski P. Decomposition of changes in life expectancy by age groups, Poland, 1950-2008. Przegl Epidemiol 2010;64(3):425-30, 9 ref. [in Polish].

68. Szyszkowicz M, Rowe B. Air pollution and emergency department visits for chest pain and weakness in Edmonton, Canada. Int J Occup Med Environ Health 2010;23(1):15-9, 8 ref. DOI: 10.2478/V10001010-0001-z.

69. Vainauskas S, Venckiene R, Krisiuleviciene D, Chomentauskas A, Januskevicius V, Vasilavicius P. Trends in the incidence of occupational diseases in Lithuania between 1999 and 2008. Int J Occup Med Environ Health 2010;23(4):317-22, 26 ref. DOI: 10.2478/ v10001-010-0027-2.

70. Vaz K, McGrowder D, Crawford T, Alexander-Lindo RL, Irving R. Prevalence of injuries and reporting of accidents among health care workers at the University Hospital of the West Indies. Int J Occup Med Environ Health 2010;23(2):133-43, 41 ref. DOI: 10.2478/ v10001-010-0016-5. 
71. Waage S, Pallesen S, Moen BE, Bjorvatn B. Shift work and age in the offshore petroleum industry. Int Marit Health 2010;61(4):251-7, 32 ref.

72. Waśkiewicz A. Quality of nutrition and level of health knowledge in young adult Polish population - the WOBASZ project. Probl Hig Epidemiol 2010;91(2):233-7, 32 ref. [in Polish].

73. Werbińska-Sienkiewicz B, Staszewska E, Rosińska M. HIV and AIDS in Poland in 2008. Przegl Epidemiol 2010;64(2):265-71 [in Polish].

74. Wilczyńska U, Szeszenia-Dąbrowska N. Occupational diseases among health and social workers in Poland. Med Pr 2010;61(6):597-605, 7 ref. [in Polish].

75. Wilczyńska U, Szeszenia-Dąbrowska N, Sobala W. Occupational diseases in Poland, 2009. Med Pr 2010;61(4):369-79, 5 ref. [in Polish].

76. Wojcierowska A, Renn-Żurek A, DziedziczakBuczyńska M, Stempień M. Preventive programs for women in the voivodeship of Lodz. Probl Hig Epidemiol 2010;91(3):511-6, 14 ref. [in Polish].

77. Wójkowska-Mach J, Jurkiewicz-Badacz D, Chmielarczyk A, Foryciarz E, Baran M, Romaniszyn D, et al. Pseudo-outbreak of MRSA in the pediatric units. Przegl Epidemiol 2010;64(4):519-24, 20 ref. [in Polish].

78. Wysocki MJ, Car J. Changes of hierarchy among causes of death in some European Union countries. Przegl Epidemiol 2010;64(1):115-8, 11 ref. [in Polish].

79. Zajkowska J, Garkowski A, Pancewicz S. Vipera berus bite - epidemiology, clinical symptoms and review of treatment methods. Przegl Epidemiol 2010;64(3):38793, 24 ref. [in Polish].

80. Zajkowska JM. Transmission and circulation of tick borne pathogens (TBE and Lyme borreliosis) and the role of changing environment. Przegl Epidemiol 2010;64(4):525-31, 19 ref. [in Polish].

81. Zejda JE. Children environmental health - Polish epidemiological publications in the global literature on the topic. Przegl Epidemiol 2010;64(3):333-9, 7 ref. [in Polish].

82. Zieliński A, Czarkowski MP. Infectious diseases in Poland in 2008. Przegl Epidemiol 2010;64(2):151-8 [in Polish].

83. Znyk M. Hepatitis C in Lodzkie voivodeship in 20032008. Przegl Epidemiol 2010;64(3):367-72, 17 ref. [in Polish].

\section{DIAGNOSTICS AND THERAPY OF ACUTE POISONING}

1. Brzeski Z, Sodolski W, Chwedorowicz R. Suicidal attempts among young rural inhabitants. Med Srod 2010;13(2):70-3, 9 ref. [in Polish].

2. Krakowiak A, Kotwica M, Śliwkiewicz K. Poisonings with street drugs: a review of 1993-2008 data from the Toxicology Unit in Poland. Int J Occup Med Environ Health 2010;23(4):357-65, 16 ref. DOI: 10.2478/v10001010-0038-z.

3. Kranz K, Marcinkowski JT. Threat of psychoactive substances and possibilities of preventive actions. Probl Hig Epidemiol 2010;91(3):364-8, 22 ref. [in Polish].

4. Kułaga Z, Napieralska E, Gurzkowska B, Grajda A. Trends in children and adolescents deaths due to suicide, event of undetermined intent and poisoning in Poland in the years 1999-2007. Przegl Epidemiol 2010;64(4): 551-6, 17 ref. [in Polish].

5. Lucas D, Lodde B, Jegaden D, Bronstein JA, Pougnet R, Bell S, et al. Occupational poisoning by carbon monoxide aboard a gas carrier. Report on 8 cases. Int Marit Health 2010;61(3):176-9, 9 ref.

6. Marciniak B, Ferenc T, Kusowska J, Ciećwierz J, Kowalczyk E. Poisoning with selected mushrooms with neurotropic and hallucinogenic effect. Med Pr 2010;61(5): 583-95, 37 ref. [in Polish].

7. Nowacka A, Olszowy Z, Kapala M, Anczyk E, Miśkiewicz Ł. Drugs — "way" of life. Med Srod 2010;13(4): 45-9, 12 ref. [in Polish]. 
8. Skoczyńska A, Poręba R. Selected problems related to environmental heavy metals exposure and chelation therapy. Med Srod 2010;13(3):62-7, 35 ref.

9. Solińska-Lewna B, Hermelin A. Phosgene poisoning: Case reports. Med Pr 2010;61(1):101-4, 8 ref. [in Polish].

\section{OCCUPATIONAL PHYSIOLOGY, PSYCHOLOGY, SOCIOLOGY AND ERGONOMICS}

1. Agaoglu SA, Tasmektepligil MY, Atan T, Tutkun E, Hazar F. Effects of two months training on blood lactate levels in adolescent swimmers. Biol Sport 2010;27(2): 135-41, 33 ref.

2. Allen P, Wellens B, Smith A. Fatigue in British fishermen. Int Marit Health 2010;61(3):154-8, 21 ref.

3. Andysz A, Waszkowska M, Merecz D, Drabek M. Use of driving simulators in psychological research. Med Pr 2010;61(5):573-82, 66 ref. [in Polish].

4. Baka , Cieślak R. Self-efficacy and social support and the effects of job stressors on job burnout and work engagement in teachers. Stud Psychol 2010;48(3):5-18, 53 ref. [in Polish].

5. Bartuzi P, Kamińska J. Musculoskeletal load and disorders and workers' knowledge about the ergonomics of a computer workstand. Bezpiecz Pr 2010;2:21-3, 9 ref. [in Polish].

6. Bertrandt J, Kłos A, Bertrandt B, Conder M. Dietary supplements in the army. Lek Wojsk 2010;88(3):28692, 20 ref. [in Polish].

7. Biernat E, Tomaszewski P, Milde K. Physical activity of office workers. Biol Sport 2010;27(4):289-96, 33 ref.

8. Binkowska-Bury M, Kruk W, Szymańska J, Marć M, Penar-Zadarko B, Wdowiak L. Psychosocial factors and health-related behavior among students from SouthEast Poland. Ann Agric Environ Med 2010;17(1):10713, 33 ref.

9. Bogdan A. Methods of evaluation of moderate thermal environment according to EN ISO 7730. Podst Met Oceny Srod Pr 2010;26(1):93-100, 7 ref. [in Polish].
10. Bogdan A. A method of assessing risk during work in cold environments. Bezpiecz Pr 2010;9:26-8, 4 ref. [in Polish].

11. Bogdan A. Evaluation of human' thermal comfort and heat stress using virtual thermal manikin. Bezpiecz $\operatorname{Pr}$ 2010;11:8-11, 13 ref. [in Polish].

12. Boryczka M. The ergonomic evaluation of workplace equipped with computer. Pr Zdrow Bezpiecz 2010;(2):24-8, 17 ref. [in Polish].

13. Brzezińska AI, Zwolińska K. Marginalization of people with disabilities connected with mental disorders. Polit Spol 2010;37(2):16-22, 23 ref. [in Polish].

14. Burstin A, Brown R. Virtual environments for real treatments. Pol Ann Med 2010;17(1):101-11, 26 ref.

15. Chodkiewicz J. The overuse of alcohol by young men and women. The importance of temperamental and dispositional factors. Czas Psychol 2010;16(2):181-8, 41 ref. [in Polish].

16. Collins S, Karasek R. Reduced vagal cardiac control variance in exhausted and high strain job subjects. Int J Occup Med Environ Health 2010;23(3): 267-78, 26 ref. DOI: 10.2478/v10001-010-0023-6.

17. Czepita D, Mojsa A, Ustianowska M, Czepita M, Lachowicz E. Reading, writing, working on a computer or watching television, and myopia. Klin Oczna 2010;112(10-12):293-5, 15 ref.

18. Derbis R, Jędrek K. The sense of quality of life and personality of individual and team sportsmen. Przegl Psychol 2010;53(1):9-32, 76 ref. [in Polish].

19. Dudek B, Hauk M. Brief scale of vocational stress (BSVS). Med Pr 2010;61(4):479-87, 23 ref. [in Polish].

20. Dudek B, Hauk M. Reactivity and job choice. Przegl Psychol 2010;53(2):195-210, 38 ref. [in Polish].

21. Erenkfeit K, Muszyńska-Graca M, Sadkowski W, Hom A, Bazylewicz A, Brewczyński PZ. The selected aspects of sociological and demographic characteristic of pneumoconiosis patients. Introductory results of a sociological survey. Med Srod 2010;13(1):86-91, 4 ref. [in Polish]. 
22. Gierlotka S. The influence of labour effort and thermal discomfort on a human body's impedance. Pr Zdrow Bezpiecz 2010;3-4:6-8, 4 ref. [in Polish].

23. Gil SM, Gil J, Ruiz F, Irazusta A, Irazusta J. Anthropometrical characteristics and somatotype of young soccer players and their comparison with the general population. Biol Sport 2010;27(1):17-24, 30 ref.

24. Goździewicz A, Mikiewicz A. Openness to international career of Polish and French students. Stud Psychol 2010;48(1):5-18, 30 ref. [in Polish].

25. Gronowska A, Kwiatkowska D, Pokrywka A, Koteras M, Turek-Lepa E, Szutowski MM. The alteration of the urinary steroid profile under the stress. Biol Sport 2010;27(1):2-9, 18 ref.

26. Huber L. Styles of adaptive mechanisms to situations of stress among people of different age and the 21st century civilization diseases. Probl Hig Epidemiol 2010;91(2):268-75, 6 ref. [in Polish].

27. Huebner SM. Demonstration of a positive effect of emotional expression on blood coagulation is possible with dark field microscopy. Pol Ann Med 2010;17(1): 54-62, 13 ref.

28. Indyk A, Erenkfeit K. Impact of individual predispositions and workplace conditions on addictedness. Med Srod 2010;13(4):50-6, 11 ref. [in Polish].

29. Jaworski J, Klimek AT, Wieczorek T. Family studies of somatic and functional characteristics in the Polish rural population. Biol Sport 2010;27(3):207-12, 28 ref.

30. Jędrych M, Jodłowska-Jędrych B, Michalska A, Kowalska AJ, Sak J. The phenomenon of aggression among school-age adolescents. Med Ogolna 2010;16(3):41626, 21 ref. [in Polish].

31. Jurczyńska G, Hom A, Kowalska-Jackiewicz J, Muszyńska-Graca M, Smolicha W. Personality and computer addiction. Med Srod 2010;13(4):57-60, 16 ref. [in Polish].

32. Jurewicz J, Hanke W, Sobala W, Merecz D, Radwan M. The effect of stress on the semen quality. Med Pr 2010;61(6):607-13, 23 ref. [in Polish].
33. Kayatekin BM, Ozcaldiran B, Aksu I, Topcu A, Ustuntas AE, Acikgoz O, et al. Effects of swimming on erythrocyte rheological properties. Biol Sport 2010;27(2): 99-103, 40 ref.

34. Kazenas A. Psychosocial risk factors in hotels, restaurants and the catering sector. Bezpiecz Pr 2010;7-8: 17-9, 11 ref. [in Polish].

35. Kilinc F. Effects of vitamin $C$ and $E$ combination on hormonal, enzymatic and hematological values in blood of forced training basketball players. Biol Sport 2010;27(1):29-33, 19 ref.

36. Klimek AT, Lubkowska A, Szyguła Z, Chudecka M, Frączek B. Influence of the ten sessions of the whole body cryostimulation on aerobic and anaerobic capacity. Int J Occup Med Environ Health 2010;23(2): 181-9, 37 ref. DOI: 10.2478/v10001-010-0019-2.

37. Kortum E, Leka S, Cox T. Psychosocial risks and workrelated stress in developing countries: health impact, priorities, barriers and solutions. Int J Occup Med Environ Health 2010;23(3):225-38, 56 ref. DOI: 10.2478/ v10001-010-0024-5.

38. Kowalczuk K, Krajewska-Kułak E, Kułak W, Ostapowicz Van Damme K, Klimaszewska K, Rolka H. Influence of aggression on stress development in the population of nurses and midwives in the Podlaskie Province. Probl Hig Epidemiol 2010;91(3):444-50, 14 ref.

39. Kowalska AJ, Jarosz MJ, Sak J, Pawlikowski J, Patryn R, Pacian A, et al. Ethical aspects of physicianpatient communication. Med Ogolna 2010;16(3): 427-35, 20 ref. [in Polish].

40. Kowalska M, Bugajska J, Żołnierczyk-Zreda D. Frequency of burnout syndrome in office workers. Med Pr 2010;61(6):615-23, 23 ref. [in Polish].

41. Krajewska-Kułak E, Kulak W, Wieczorek B, Guzowski A, Van Damme-Ostapowicz K, Lukaszuk C, et al. Evaluation of mobile phone addiction hazard among students of nursing. Probl Hig Epidemiol 2010;91(3): 375-80, 12 ref. [in Polish]. 
42. Krajewska-Kułak E, Kułak W, Van Damme-Ostapowicz $\mathrm{K}$, Lewko J, Łukaszuk C, Bielemuk A, et al. Internet addiction among nursing students. Probl Hig Epidemiol 2010;91(1):41-7, 21 ref. [in Polish].

43. Kubicka K, Pierzchała K, Pyrtek S. The emotionality and the level of stress in employees of a hospital and workers of a coking plant. Med Srod 2010;13(1): 78-85, 13 ref. [in Polish].

44. Kułak W, Kondzior D. Discopathy of the lumbar spine in relation to intensity of pain, depression and illness acceptance. Probl Hig Epidemiol 2010;91(1):153-7, 24 ref. [in Polish].

45. Kunecka D. Employee's satisfaction and medical service quality. Probl Hig Epidemiol 2010;91(3):451-7, 37 ref. [in Polish].

46. Kurkcu R, Cakmak A, Zeyrek D, Atas A, Karacabey K, Yamaner F. Evaluation of oxidative status in short-term exercises of adolescent athletes. Biol Sport 2010;27(3):177-80, 39 ref.

47. Kurowska K, Prus N. The role of support and sense of coherence in dealing with hypertensive disease. Nadcisn Tetn 2010;14(5):387-94, 16 ref. [in Polish].

48. Leszczyńska I, Jeżewska M. Psychosocial burden among offshore drilling platform employees. Int Marit Health 2010;61(3):159-67, 24 ref.

49. Lipińska-Grobelny A, Wasiak K. Job satisfaction and gender identity of women managers and non-managers. Int J Occup Med Environ Health 2010;23(2): 161-6, 24 ref. DOI: 10.2478/v10001-010-0015-6.

50. Lovell GP, Townrow J, Thatcher R. Mood states of soccer players in the English leagues: reflections of an increasing workload. Biol Sport 2010;27(2):83-8, 24 ref.

51. Lubkowska A, Szyguła Z. Changes in blood pressure with compensatory heart rate decrease and in the level of aerobic capacity in response to repeated whole-body cryostimulation in normotensive, young and physically active men. Int J Occup Med Environ Health 2010;23(4): 367-75, 37 ref. DOI: 10.2478/v10001-010-0037-0.
52. Łaszek M, Nowacka E, Szatko F. Do the nervous system dysfunctions predispose to the use of psychoactive substances? Probl Hig Epidemiol 2010;91(3):48994, 14 ref. [in Polish].

53. Maciak A, Bryła M, Maniecka-Bryła I. Stress as a risk factor of ischaemic hearth disease among participants of the Programme of Preventive Measures in an Early Detection of Circulatory System Diseases. Zdrow Publiczne 2010;120(4):337-40, 15 ref.

54. Makara-Studzińska M, Morylowska-Topolska J, Wdowiak A, Urbańska A. Health behaviours in women treated for infertility and their influence on the incidence of depression. Zdrow Publiczne 2010;120(2): 112-7, 14 ref.

55. Malara M, Lutosławska G. Physical activity, dietary habits and plasma lipoproteins in young men and women. Rocz Panstw Zakl Hig 2010;61(4):405-12, 49 ref. [in Polish].

56. Malinowska D, Tokarz A, Gad N. A preliminary adaptation study of Spence and Robbins' Workaholism Battery (Work-Bat). Stud Psychol 2010;48(3):35-42, 35 ref. [in Polish].

57. Maliszewska D, Bojar I, Woźnica I, Owoc A, Diatczyk J. Psychological aspects of sharing knowledge at a workplace based on example of a group of nurses from Warsaw hospitals. Med Ogolna 2010;16(2): 276-89, 9 ref. [in Polish].

58. Mazurek K, Żmijewski P, Czajkowska A, Lutosławska G. Cardiovascular risk in students with different level of aerobic capacity. Biol Sport 2010;27(2):105-9, 24 ref.

59. Mędrela-Kuder E. Physical activity as an additional way of rehabilitation of type 2 diabetes sufferers. Rocz Panstw Zakl Hig 2010;61(1):87-90, 12 ref. [in Polish].

60. Mościcka A. Preventive care in the area of psychosocial risk at work. Med Pr 2010;61(1):91-100, 26 ref. [in Polish].

61. Mościcka A, Drabek M. Individual and environmental antecedents of mobbing. Med Pr 2010;61(4): 467-77, 54 ref. [in Polish]. 
62. Mróz J. The role of social support in the process of cardiologic rehabilitation. Zdrow Publiczne 2010;120(4): 341-5, 15 ref.

63. Nowak A. The impact of work time on family time basing on time use surveys. Polit Spol 2010;37(3): 14-9, 39 ref. [in Polish].

64. Ogurkowska MB. Analysis of radiological characteristics distribution in the vertebral bodies of the lumbosacral spine of competitive rowers. Biol Sport 2010;27(3): 213-9, 26 ref.

65. Orzeł-Gryglewska J. Consequences of sleep deprivation. Int J Occup Med Environ Health 2010;23(1): 95-114, 160 ref. DOI: 10.2478/v10001-010-0004-9.

66. Pas-Wyroślak A, Wagrowska-Koski E. Effect of visual work on the tear film and degree of the eye strain. Med Pr 2010;61(5):527-35, 30 ref. [in Polish].

67. Pas-Wyroślak A, Wagrowska-Koski E, Jurowski P. Assessment of the impact of the visual work with display monitors on the eye temperature and intraocular pressure. Med Pr 2010;61(6):625-33, 33 ref. [in Polish].

68. Pawłowska K. Motivating people with disabilities to take up and keep jobs. Bezpiecz Pr 2010;7-8:24-7, 7 ref. [in Polish].

69. Pietraszkiewicz T, Borodulin-Nadzieja L, Janocha A, Woźniak W, Stańda M. Evaluation of telemetric method in the assessment of heat stress of copper miners. Med Pr 2010;61(1):35-42, 10 ref. [in Polish].

70. Pietryka-Michałowska E, Szymańska J, Jurkowska B. Lifestyle of women with cancer. Part III. Impact of cancer on mental health of women. Zdrow Publiczne 2010;120(2):124-7, 7 ref.

71. Piłka E, Jędrzejczak W, Piotrowska A, Lorens A, Kochanek K, Skarżyński H. Detection of otoacoustic emissions in the $500 \mathrm{~Hz}$ band: normal hearing subjects. Otorynolaryngologia 2010;9(2):76-81, 14 ref. [in Polish].

72. Piłka E, Jędrzejczak WW, Piotrowska A, Lorens A, Kochanek K, Skarżyński H. Detection of otoacoustic emissions in the $500 \mathrm{~Hz}$ band: patients with partial deafness.
Otorynolaryngologia 2010;9(4):187-94, 19 ref. [in Polish].

73. Piotrowska-Całka E. Effects of a 24-week deep water aerobic training program on cardiovascular fitness. Biol Sport 2010;27(2):95-8, 25 ref.

74. Poraj G. Psychological models of female teachers' functioning in their professional role. Int J Occup Med Environ Health 2010;23(1):33-46, 51 ref. DOI: 10.2478/ v10001-010-0007-6.

75. Pori P, Tusak M, Pori M. Which motor abilities have the highest impact on working performance of Slovenian soldiers? Biol Sport 2010;27(4):301-5, 20 ref.

76. Potocka A. What do we know about psychosocial risk factors at work? Part I. Theoretical considerations. Med Pr 2010;61(3):341-52, 36 ref. [in Polish].

77. Potocka A, Merecz-Kot D. What do we know about psychosocial risks at work? Part II. The analysis of employee's knowledge of sources and consequences of stress at work. Med Pr 2010;61(4):393-411, 15 ref. [in Polish]. 78. Pourvaghar MJ, Ghaeini AA, Ravasi AA, Kordi MR. Effects of training time on serum immunoglobulin alterations and cortisol testosterone responses in male athlete students. Biol Sport 2010;27(1):25-8, 13 ref.

79. Roman-Liu D, Tokarski T. Assessing static load with OWAS. Bezpiecz Pr 2010;7-8:28-31, 6 ref. [in Polish].

80. Rydstedt LW, Lundh M. An Ocean of stress? The relationship between psychosocial workload and mental strain among engine officers in the Swedish merchant fleet. Int Marit Health 2010;61(3):168-75, 40 ref.

81. Samochowiec A. The influence of parents personality measured by temperamental and character inventory (TCI) on course of alcoholism characterized by Cloninger's and Lesch's typologies. Ann Acad Med Stetin 2010;56(2):33-9, 20 ref.

82. Saus ER, Johnsen BH, Eid J. Perceived learning outcome: the relationship between experience, realism, and situation awareness during simulator training. Int Marit Health 2010;61(4):258-64, 21 ref. 
83. Skarpańska-Stejnborn A, Basta P, PilaczyńskaSzcześniak Ł, Horoszkiewicz-Hassan M. Black grape extract supplementation attenuates blood oxidative stress in response to acute exercise. Biol Sport 2010;27(1): 41-6, 46 ref.

84. Sobczak MD, Andruszkiewicz A, Banaszkiewicz M. Education as a factor contributing to the development of nurses' assertiveness. Zdrow Publiczne 2010;120(1): 76-9, 10 ref.

85. Supranowicz P, Wysocki MJ. School stress and health disorders of post-elementary school adolescents. Rocz Panstw Zakl Hig 2010;61(2):171-8, 21 ref. [in Polish].

86. Szosland D. Shift work and metabolic syndrome, diabetes mellitus and ischaemic heart disease. Int J Occup Med Environ Health 2010;23(3):287-91, 37 ref. DOI: 10.2478/v10001-010-0032-5.

87. Szymańska J, Pietryka-Michałowska E, ToruńJurkowska A. Lifestyle of women with cancer. Part IV. Family support in the battle with cancer. Zdrow Publiczne 2010;120(2):128-31, 11 ref.

88. Tumińska A, Borodulin-Nadzieja L, Pietraszkiewicz T, Salomon E, Stańda M, Woźniak W, et al. Analysis of the Holter records in miners working at the deepest located work stations in copper mines of the LegnicaGłogów copper mining district. Med Pr 2010;61(1): 43-54, 17 ref. [in Polish].

89. Tworus R, Szymańska S, Ilnicki S. Comprehensive therapy of PTSD in a soldier of the Polish Military Contingent using virtual reality and behavioral training in vivo. Lek Wojsk 2010;88(3):269-74, 8 ref. [in Polish].

90. Waszkowska M, Drabek M. Psychological factors for planning early retirement. Med Pr 2010;61(5): 537-47, 29 ref. [in Polish].

91. Waszkowska M, Merecz D, Drabek M. Stress prevention programs - strategies, techniques, effectiveness. Part II. Organizational activities to prevent stress at work. Med Pr 2010;61(2):191-204, 50 ref. [in Polish].
92. Winiarska-Mieczan A, Poterucha E. Risk of anorexia and bulimia among female students of universities in Lublin. Probl Hig Epidemiol 2010;91(1):15863, 30 ref. [in Polish].

93. Wojdyło K. Functioning of workaholics in the task situation. Przegl Psychol 2010;53(1):61-82, 49 ref. [in Polish].

94. Wojdyło K, Buczny J. Workaholism questionnaire: WART-R. Validity and reliability analysis. Stud Psychol 2010;48(1):67-80, 46 ref. [in Polish].

95. Wontorczyk A. Problems of risk taking in transport and traffic psychology. Czas Psychol 2010;16(2):20923, 169 ref. [in Polish].

96. Wołowska A, Bańka A, Bazińska R. The effect of breaching the psychological contract on job involvement. The mediating role of psychological climate. Czas Psychol 2010;16(2):225-35, 60 ref. [in Polish].

97. Wróbel M. Affective contagion at work. Causes and effects of collective moods and emotions. Med Pr 2010;61(2):223-32, 70 ref. [in Polish].

98. Zaczyk I. Occupational burnout and the sense of coherence among pediatric nurses. Zdrow Publiczne 2010;120(4):417-20, 16 ref.

99. Zwolińska M, Bogdan A. Thermal insulation of clothing. Bezpiecz Pr 2010;2:17-20, 8 ref. [in Polish].

100. Żołnierczyk-Zreda D. Stress at work - where are we currently? Bezpiecz Pr 2010;10:6-7, 7 ref. [in Polish].

\section{THE OCCUPATIONAL HEALTH CARE SYSTEM}

1. Abramowicz J. The role and tasks of medical staff during war and during peacekeeping and stabilization missions. Lek Wojsk 2010;88(1):67-72, 18 ref. [in Polish].

2. Anczyk E, Anczyk A. Medical ethos in the field of interpersonal relations. Med Srod 2010;13(1):123-8, 15 ref. [in Polish].

3. Bartkowiak G. Directions in developing intelligent clothing. Bezpiecz Pr 2010;1:18-22, 12 ref. [in Polish]. 
4. Baszczyński K, Jachowicz M. Guidelines for users' assessment of the physical condition of industrial safety helmets. Bezpiecz Pr 2010;2:10-2, 7 ref. [in Polish].

5. Bielski M, Krawczyk A. Aviation safety. Bezpiecz $\operatorname{Pr}$ 2010;4:10-3, 12 ref. [in Polish].

6. Bochniak A. Healthy habits as an element of a healthy lifestyle. Lek Wojsk 2010;88(2):187-94, 27 ref. [in Polish].

7. Bojar I, Szymańska J. Warranty of occupational health and safety within public health insurance in public opinion in Poland. Zdrow Publiczne 2010;120(1):813, 16 ref.

8. Boratyn-Dubiel L, Chmiel Z. Importance of health education among patients with diabetes. Zdrow Publiczne 2010;120(3):316-23, 36 ref. [in Polish].

9. Brudecki J. The role of health education in promotion of health-related fitness concept. Rocz Panstw Zakl Hig 2010;61(4):401-3, 16 ref. [in Polish].

10. Bugajska J, Makowiec-Dąbrowska T, WągrowskaKoski E. Age management in enterprises as a part of occupational safety and health in elderly workers. Med Pr 2010;61(1):55-63, 36 ref. [in Polish].

11. Cebulska-Wasilewska A, Majewska R, Drąg Z. Study on students' awareness concerning environmental and occupational hazardous agents of cancer risk and prevention methods. Med Srod 2010;13(3):50-61, 15 ref. [in Polish].

12. Cianciara D. Specialisation programme in health promotion and health education in Poland versus core competencies in these fields. Przegl Epidemiol 2010;64(1): 139-46, 21 ref. [in Polish].

13. Cianciara D, Piotrowicz M, Dmowski M, Tucka-Dorociak H. Workforce in public health and health promotion in Poland. Part I. Size of the workforce. Probl Hig Epidemiol 2010;91(3):468-74, 11 ref. [in Polish].

14. Cianciara D, Piotrowicz M, Gajewska M. Workforce in public health and health promotion in Poland. Part III. Career expectations among public health students. Probl Hig Epidemiol 2010;91(3): 482-8, 17 ref. [in Polish].

15. Cianciara D, Piotrowicz M, Tucka-Dorociak H. Workforce in public health and health promotion in Poland. Part II. Job offers. Probl Hig Epidemiol 2010;91(3): 475-81, 11 ref. [in Polish].

16. Collegium Ramazzini. Asbestos is still with us: repeat call for a universal ban. Int J Occup Med Environ Health 2010;23(2):201-7, 54 ref. DOI: 10.2478/v10001010-0017-4.

17. Dahl E. Passenger accidents and injuries reported during 3 years on a cruise ship. Int Marit Health 2010;61(1): $1-8,15$ ref.

18. Dahl E. Call for a universally accepted surveillance and reporting form for acute gastroenteritis (AGE) on ships. Int Marit Health 2010;61(2):99-100, 2 ref.

19. Dahl E, Diskin A, Giusti AC, Bile A, Williams S. A first response bag with standardized contents for medical emergencies on cruise ship. Int Marit Health 2010;61(1): 18-23, 6 ref.

20. Demidowicz J, Kowalska J, Tyszko P. Local programs of cancer prevention in realization of the National Health Program on the example of selected voivodeships. Probl Hig Epidemiol 2010;91(3):463-7, 8 ref. [in Polish].

21. Derkacz M, Chmiel-Perzyńska I, Marczewski K. Obesity as an interdisciplinary medical problem (Part II). Effect on human health. Med Ogolna 2010;16(2): 175-83, 76 ref. [in Polish].

22. Duda A. New Directive on Machinery 2006/42/WE - the most important changes introduced in the domain of basic requirements concerning health protection and safety. Pr Zdrow Bezpiecz 2010;3-4:12-8, 6 ref. [in Polish].

23. Dudek J. OSH management in libraries. Bezpiecz Pr 2010;6:16-8 [in Polish].

24. Farin K. Safety at work in photography. Bezpiecz Pr 2010;7-8:7-9, 7 ref. [in Polish].

25. Fijałek Z, Sarna K, Błażewicz A, Marin J. Counterfeit phosphodiesterase type 5 inhibitors - growing 
safety risks for public health. Rocz Panstw Zakl Hig 2010;61(3):227-35, 25 ref. [in Polish].

26. Florek-Łuszczki M. Level of knowledge of breast cancer risk factors and prophylactic principles among female rural inhabitants. Med Ogolna 2010;16(3):406-15, 12 ref. [in Polish].

27. Furtak M, Książek P, Rzemek C, Zdrojkowski J. Educating managers as a key factor in effective management of healthcare units. Zdrow Publiczne 2010;120(3): 213-7, 8 ref. [in Polish].

28. Gacek M. Selected lifestyle and health condition indices of adults with varied models of eating. Rocz Panstw Zakl Hig 2010;61(1):65-9, 17 ref. [in Polish].

29. Gacek M. Some health behaviours and selected health status coefficients in a group of pregnant women. Probl Hig Epidemiol 2010;91(1):48-53, 35 ref. [in Polish].

30. Gajek A, Michalik JS, Janik P, Dziwulski D, Zając S, Adamczyk A, et al. Non-Seveso establishments: branches and types of establishments, dangerous chemical substances and major accident risk management. Bezpiecz Pr 2010;4:14-8, 4 ref. [in Polish].

31. Gajek A, Michalik JS, Rutkowska H, Janik P, Dziwulski D, Zając S. The Inspection of Environmental Protection and the State Fire Service's principles of identifying non-Seveso establishments producing a hazard of a major accident. Bezpiecz Pr 2010;3:12-6, 9 ref. [in Polish].

32. Gierasimiuk J. Harmonizing machinery with the new 2006/42/EC machinery directive. Bezpiecz Pr 2010;1:8-13, 15 ref. [in Polish].

33. Godala M, Szatko F. Notifiability of infectious diseases. Part I. Assessment of physicians' awareness regarding reporting infectious diseases to the Sanitary Inspection. Probl Hig Epidemiol 2010;91(2):198-205, 14 ref. [in Polish].

34. Godala M, Szatko F. Notifiability of infectious diseases. Part II. Barriers impeding full notifiability of infectious diseases to the Sanitary Inspection according to primary care physicians. Probl Hig Epidemiol 2010;91(2):20613, 8 ref. [in Polish].
35. Goniewicz M, Goniewicz K. Road accidents in Poland - causes and prevention. Bezpiecz Pr 2010;9: 14-7, 15 ref. [in Polish].

36. Goszczyńska E. Activities of voivodeship occupational medicine centers in workplace health promotion in 2008. Med Pr 2010;61(3):353-65, 6 ref. [in Polish].

37. Graczyk A, Czerczak S, Barański B. Safe usage of chemicals in European Union countries. Med Pr 2010;61(3):333-40, 11 ref. [in Polish].

38. Gralewicz G, Jachowicz M, Baszczyński K. Electronic system for monitoring parameters of personal protective equipment. Bezpiecz Pr 2010;12:16-8, 6 ref. [in Polish].

39. Grochowska A, Schlegel-Zawadzka M. Nutrition and tobacco smoking among adolescents from secondary schools. Probl Hig Epidemiol 2010;91(1):73-6, 7 ref. [in Polish].

40. Grodzicka A, Kulaga-Tetera M. Susceptibility to risky behaviour (2). Pr Zdrow Bezpiecz 2010;3-4:9-12, 6 ref. [in Polish].

41. Gromulska L. Mental health in the world according to WHO documents. Przegl Epidemiol 2010;64(1): 127-32, 10 ref. [in Polish].

42. Gromulska L, Wysocki MJ. Evaluation of health systems. Przegl Epidemiol 2010;64(3):413-20, 11 ref. [in Polish].

43. Grzelewska A, Granosik A, Przybyła J, Głowacka A. Prevalence, risk factors, prophylactic behavior, therapeutic behavior and state of knowledge regarding urinary tract infections among chosen population of nursing/ midwifery students and qualified nurses/midwifes from Medical University of Łódź. Med Srod 2010;13(1): 92-8, 29 ref. [in Polish].

44. Gugała B, Boratyn-Dubiel L, Chmiel Z, Januszewicz P. The Internet as a source of knowledge about health. Med Ogolna 2010;16(2):266-75, 16 ref. [in Polish].

45. Hejmdalski W. Occupational safety and health in archeology - by example of student practices. Bezpiecz Pr 2010;(10):8-12, 8 ref. [in Polish]. 
46. Herko A. Protective clothing and shoes and individual protection means. Pr Zdrow Bezpiecz 2010;2:22-4 [in Polish].

47. Holecki T, Bocionek A. Electronic exchange of social security data. Polit Spol 2010;37(11-12):36-8, 8 ref. [in Polish].

48. Huzarska D, Piątkiewicz JA, Nowacki P, Huzarska J, Szpak A. Differences in professional liability in health care - legal regulations. Zdrow Publiczne 2010;120(3):286-91, 22 ref. [in Polish].

49. Idnani N. Varicella among seafarers: a case study on testing and vaccination as a cost-effective method of prevention. Int Marit Health 2010;61(1):32-5, 16 ref.

50. Jankowiak M. Convergence of health care in European Union member states. Polit Spol 2010;37(7): 6-10, 14 ref. [in Polish].

51. Janukowicz P. Registered unemployment vs. unemployment according to the Labour Force Survey (BAEL). Polit Spol 2010;37(1):18-20, 10 ref. [in Polish].

52. Jassem E, Górecka D, Krakowiak P, Kozielski J, Słomiński JM, Krajnik M, et al. Integrated care for patients with advanced chronic obstructive pulmonary disease. Pneumonol Alergol Pol 2010;78(2): 126-32, 40 ref. [in Polish].

53. Kaczyński P. High altitude work. Extreme sports? Bezpiecz Pr 2010;12:22-4 [in Polish].

54. Kanicka M, Krupicka A, Krysińska M, Lewkowicz M, Manias S, Kowalska A, et al. Tobacco smoking-related knowledge and attitudes of public health faculty students of Medical University of Bialystok. Probl Hig Epidemiol 2010;91(1):164-8, 13 ref. [in Polish].

55. Kanicka M, Szpak A, Karpińska M. Prevalence of tobacco smoking and measures preventing tobacco smoke inhalation among third grade secondary school students in Bialystok. Zdrow Publiczne 2010;120(3): 218-21, 14 ref.

56. Kapka L, Cyranka M, Szymańska J, Krasowska E, Skrzypczak M. The WHO Healthy Cities project realisation in Poland in last few years. Zdrow Publiczne 2010;120(3):300-5, 18 ref. [in Polish].

57. Kapka L, Perżyło K, Cyranka M, Skrzypczak M, Wdowiak L. Congenital toxoplasmosis as a relevant health problem. Zdrow Publiczne 2010;120(1):80-6, 25 ref. [in Polish].

58. Kapka-Skrzypczak L, Woźnica I, Ćwikła S, Skrzypczak M, Diatczyk J, Wdowiak L. Hospital base in Poland and worldwide. Med Ogolna 2010;16(3):391405, 10 ref. [in Polish].

59. Klimek D. Contract employment in national health service - a chance or a danger? Polit Spol 2010;37(7): 10-5, 4 ref. [in Polish].

60. Kolasa K. Principle of equity and solidarity and outof-pocket health care payments. A comparative study between Poland and Sweden. Polit Spol 2010;37(10): 17-24, 17 ref. [in Polish].

61. Kołłątaj W, Kołłątaj B, Karwat ID, PiecewiczSzczęsna H. Attitudes of students of Medical University of Lublin towards tobacco smoking. Probl Hig Epidemiol 2010;91(3):495-500, 22 ref. [in Polish].

62. Korzeniewski K. The structure of morbidity among soldiers of the Polish Military Contingent in Chad from 2008 to 2009. Lek Wojsk 2010;88(1):7-13, 29 ref. [in Polish]. 63. Korzeniewski K. The program for the prevention of parasite-borne digestive diseases in soldiers of the Polish Armed Forces stationed abroad. Lek Wojsk 2010;88(1): 60-6, 27 ref. [in Polish].

64. Korzeniewski K, Skórczewski K. Activities of the Polish Military Contingent in Chad in the years 2008-2009. Lek Wojsk 2010;88(2):164-71, 23 ref. [in Polish].

65. Kowalska M, Marcinkowska U, Jośko J. Occupational satisfaction and quality of life in women aged 45-60 years in the Silesia voivodeship. Med Pr 2010;61(3): 277-85, 22 ref. [in Polish].

66. Krause M. Prevention in the domain of health and safety at work. Pr Zdrow Bezpiecz 2010;1:13-7, 7 ref. [in Polish]. 
67. Krause M. Principles of identification of mechanical hazards in working environment. Pr Zdrow Bezpiecz 2010;2:16-21, 25 ref. [in Polish].

68. Krisciunas A, Kowalski IM. Ensuring rehabilitation and full quality of life for patients with chronic non-infectious diseases. Pol Ann Med 2010;17(1):112-22, 13 ref.

69. Krzyśków B. Occupational safety and health for young people undertaking training during unemployment. Bezpiecz Pr 2010;7-8:20-3 [in Polish].

70. Krzyśków B. Working conditions of part-time employees survey results. Bezpiecz Pr 2010;11:20-3 [in Polish].

71. Kurowska A. Barriers to the activity of young mothers on the labour market in Poland. Polit Spol 2010;37(11-12): 11-8, 27 ref. [in Polish].

72. Kurpiewska J, Liwkowicz J. Guidelines on skin protection measures (1). Bezpiecz Pr 2010;6:23-5, 15 ref. [in Polish].

73. Kurpiewska J, Liwkowicz J. Guidelines on skin protection measures (2). Bezpiecz Pr 2010;7-8:32-4, 8 ref. [in Polish].

74. Lau K, Jośko J. Sleep disorders as a public health problem. Zdrow Publiczne 2010;120(2):199-202, 38 ref.

75. Lodde B, Lucas D, Pougnet R, Jegaden D, Bronstein JA, Dewitte JD. Deaths on board: medical and legal implications for the maritime physician. Int Marit Health 2010;61(1):24-7, 30 ref.

76. Lubiński W, Omernik A. Quality of care for patients with asthma and COPD provided by family doctors and medical specialists in Poland. Lek Wojsk 2010;88(2): 103-10, 9 ref. [in Polish].

77. Łangowski K. Legal proceedings concerning safety in transporting hazardous products (1) - ADR (The European Agreement Concerning the International Carriage of Dangerous Goods by Road). Bezpiecz Pr 2010;3: 17-21, 9 ref. [in Polish].

78. Łangowski K. Legal framework for transportation of dangerous materials (2) - classification. Bezpiecz $\operatorname{Pr}$ 2010;10:13-7, 8 ref. [in Polish].
79. Łapiński TW, Szulżyk T, Flisiak R. HBV infection and pregnancy. Przegl Epidemiol 2010;64(4):503-7, 21 ref. [in Polish].

80. Made Setiawan I, Patten JH. The organization of HIV/ AIDS risk-taking among long-line fishermen in Bali, Indonesia. Int Marit Health 2010;61(4):201-8, 33 ref.

81. Makles Z, Szewczyńska M. Stationery resources as a source of chemical hazards. Bezpiecz Pr 2010;7-8: 38-42, 10 ref. [in Polish].

82. Maniecka-Bryła I, Bryła M, Maciak A. Prevalence of lipid metabolism disorders among participants of the programme for early prophylaxis of cardiovascular diseases in a medium-size town. Med Ogolna 2010;16(3): 372-90, 26 ref. [in Polish].

83. Michniewicz I, Michniewicz R. Lifeguard's working environment as a key factor of rescue operation efficiency. Bezpiecz Pr 2010;10:18-21, 19 ref. [in Polish].

84. Młodzka-Stybel A. ESENER. A survey of European enterprises on new risks in the working environment. Bezpiecz Pr 2010;12:5-7, 6 ref. [in Polish].

85. Mouchtouri VA, Bartlett CLR, Jaremin B, Nichols G, Paux T, Riemer T, et al. The decision making process for public health measures related to passenger ships: the example of the influenza pandemic of 2009. Int Marit Health 2010;61(4):241-5, 22 ref.

86. Mouchtouri VA, Nichols G, Rachiotis G, Kremastinou J, Arvanitoyannis IS, Riemer T, et al. State of the art: public health and passenger ships. Int Marit Health 2010;61(2):49-98, 204 ref.

87. Muster R. Time of being unemployed versus problems of job activation of the unemployed in the light of the empirical research. Polit Spol 2010;37(3):20-6 [in Polish].

88. Najmiec A, Łuczak A. Social aspects of safety culture on the road and in transport enterprises. Bezpiecz Pr 2010;7-8:10-3, 7 ref. [in Polish].

89. Niedźwiedzka M, Nowacka E, Grzybowski A. Recruit service soldiers' hazardous behaviors conducive 
to HIV infection. Probl Hig Epidemiol 2010;91(2): 214-20, 10 ref. [in Polish].

90. Niedźwiedzka M, Nowacka E, Grzybowski A. Knowledge of recruit service soldiers concerning HIVIAIDS. Probl Hig Epidemiol 2010;91(1):118-25, 6 ref. [in Polish].

91. Niedźwiedzka M, Nowacka E, Grzybowski A. Attitudes of recruit service soldiers towards the HIVinfected and AIDS patients. Probl Hig Epidemiol 2010;91(1):126-30, 6 ref. [in Polish].

92. Nieradko-Iwanicka B, Iwanicki J. Professional activity departments: the role in professional rehabilitation of the disabled and perspectives of future development. Probl Hig Epidemiol 2010;91(2):329-31, 10 ref. [in Polish].

93. Nieradko-Iwanicka B, Iwanicki J. Occupational therapy workshop: origin, development, functions, and perspective. Probl Hig Epidemiol 2010;91(2):332-4, 11 ref. [in Polish].

94. Niewiadomski TJ, Urbaniak M, Zysnarska MM. Patient rights - mandated standards and implementation in the Wielkopolska voivodeship on the basis of patients' complaints and petitions. Probl Hig Epidemiol 2010;91(1):99-105, 12 ref. [in Polish].

95. Nikolić N. Global partnership on HIV and mobile workers in the maritime sector. Int Marit Health 2010;61(4): 189-94, 38 ref.

96. Nosko J. The role of regional and local authorities in shaping health-conducive environmental determinants in the light of the Polish legislation. Med Pr 2010;61(4): 431-48, 41 ref. [in Polish].

97. Nowak A. Disabled people's discrimination. Polit Spol 2010;37(10):12-6, 26 ref. [in Polish].

98. Nowak PF. The level of knowledge of health-oriented physical activity among post-secondary students. Zdrow Publiczne 2010;120(4):365-9, 19 ref.

99. Noworyta-Głowacka J, Bańkowski R, Wiadrowska B, Ludwicki JK. Toxicological evaluation of crop protection chemicals in the EU registration process. Rocz Panstw Zakl Hig 2010;61(1):1-6, 15 ref. [in Polish].
100. Panasiuk L, Mierzecki A, Wdowiak L, Paprzycki P, Lukas W, Godycki-Ćwirko M. Prevalence of cigarette smoking among adult population in Eastern Poland. Ann Agric Environ Med 2010;17(1):133-8, 37 ref.

101. Parczewski M, Madaliński K, Leszczyszyn-Pynka M, Boron-Kaczmarska A. Evaluation of quality of HIV diagnostic procedures in Poland. Przegl Epidemiol 2010;64(1):47-53, 15 ref. [in Polish].

102. Pawłowska Z. Implementing the requirements related to occupational risk assessment in enterprises. Bezpiecz Pr 2010;1:28-31, 6 ref. [in Polish].

103. Pęciłło M. Effectiveness of programmes modifying unsafe behaviours in enterprises. Bezpiecz Pr 2010;11: 16-9, 12 ref. [in Polish].

104. Pietryka-Michałowska E, Szymańska J, ToruńJurkowska A. Lifestyle of women with neoplastic disease. Part I. Effects of neoplastic disease on women's socio-professional performance. Zdrow Publiczne 2010;120(1):37-40, 8 ref.

105. Pinkas J, Wierzba W, Owoc A, Bojar I. Medical certification in the context of the sense of health safety. Med Ogolna 2010;16(3):436-44, 13 ref. [in Polish].

106. Pokrywka A, Kwiatkowska D, Kaliszewski P, Grucza R. Some aspects concerning modifications of the list of prohibited substances and methods in sport. Biol Sport 2010;27(4):307-14, 36 ref.

107. Pościk A. Warning clothing safe use. Bezpiecz Pr 2010;6:26-9, 11 ref. [in Polish].

108. Pułkowski M, Domański W. Safe road transportation of liquid fuels in tankers - basic obligations of participants of road traffic. Bezpiecz Pr 2010;9:9-13, 8 ref. [in Polish].

109. Racek G. From an experienced OSH expert with a CIOP-PIB certificate. Importance of periodic $\mathrm{OSH}$ analysis to OSH management. Bezpiecz Pr 2010;4: 24-5, 8 ref. [in Polish].

110. Rogowska K. 60 years of "Medycyna Pracy". Med Pr 2010;61(1):1-3, 3 ref. [in Polish]. 
111. Rogowska-Szadkowska D, Chlabicz S. Does the poor HIVIAIDS knowledge among medical students may contribute to late diagnosis? Przegl Epidemiol 2010;64(1):41-5, 22 ref.

112. Rydlewska-Liszkowska I. Return on investement for occupational health: review of methods and recommendations. Med Pr 2010;61(6):655-60, 16 ref. [in Polish].

113. Rzepecki J. Motivation impact of differentiated contribution system on social accident insurance. Bezpiecz Pr 2010;3:8-11 [in Polish].

114. Rzepecki J. Effectiveness of human resources management in terms of work safety and health (1). Bezpiecz Pr 2010;6:10-3, 15 ref. [in Polish].

115. Rzepecki J. Research on human resources management in terms of occupational safety and health in a company (2). Bezpiecz Pr 2010;9:22-5, 10 ref. [in Polish].

116. Rzepecki J. Research on human resources management in terms of occupational safety and health in a company (3). Bezpiecz Pr 2010;11:12-5, 7 ref. [in Polish].

117. Sak J, Jarosz MJ, Wiechetek M, Pawlikowski J, Włoszczak-Szubzda A, Patryn R, et al. Perception of obesity and health-oriented behaviours in the group of medical employees. Zdrow Publiczne 2010;120(2):139-43, 16 ref.

118. Sakowski P. Self-assessment of tasks and roles of occupational medicine service (OMS) nurses in the Polish system of workers' health protection. Med Pr 2010;61(5):561-72, 16 ref. [in Polish].

119. Skórczewski K. Medical intelligence - the new quality in medical coverage of military operations. Lek Wojsk 2010;88(1):48-59, 12 ref. [in Polish].

120. Skrzypczak Z. Health-related expenses in the Polish household budget. Zdrow Publiczne 2010;120(2):10711, 8 ref. [in Polish].

121. Smoder A. Work-life balance - a choice or necessity? Polit Spol 2010;37(4):12-8, 32 ref. [in Polish].
122. Sowa A. On educational inequalities in medical services utilization. Polit Spol 2010;37(9):33-6, 15 ref. [in Polish].

123. Stokłosa A, Skoczylas A, Rudnicka A, Bednarek M, Krzyżanowski K, Górecka D. Evaluation of motivation to quit smoking in outpatients attending smoking cessation clinic. Pneumonol Alergol Pol 2010;78(3):2115, 14 ref. [in Polish].

124. Sulmicka M. Public health in the light of the EU sustainable development strategy monitoring indicators. Polit Spol 2010;37(11-12):5-11, 9 ref. [in Polish].

125. Sygit K, Nasiłowska-Barud A, Karwat ID, Gorczyca R, Jędrych M, Kołłątaj W. Selected social and health problems in functioning of disabled rural and urban inhabitants in the Lublin Region - similarities and differences. Ann Agric Environ Med 2010;17(2):28799, 26 ref.

126. Szczepankiewicz EI. Internal audit as a management improvement tool in the healthcare sector units. Pol Ann Med 2010;17(1):136-48, 10 ref.

127. Szczepański M. The proposals of changes in the Polish public pension system in Poland. Polit Spol 2010;37 (5-6):18-23, 17 ref. [in Polish].

128. Szumlicz T. Public pensions system after ten years: debates concerning OPF? Polit Spol 2010;37(5-6): 24-6, 12 ref. [in Polish].

129. Szybkie A. Social security pensions under Polish-Canadian agreement on social security. Polit Spol 2010;37(11-12):23-7 [in Polish].

130. Slusarska B, Nowicki G. Health behaviours in prophylaxis of cardiovascular diseases among occupationally active population. Probl Hig Epidemiol 2010;91(1): 34-40, 22 ref. [in Polish].

131. Tansey E, Theyise N, Borland R, West H. Southern Africa ports as spaces of HIV vulnerability: case studies from South Africa and Namibia. Int Marit Health 2010;61(4):233-40, 10 ref. 
132. Tarhoni M, Kuszewski K. Economical situation of public payer and financing of medical benefits during the years of 1999-2010. Przegl Epidemiol 2010;64(1): 109-14, 12 ref. [in Polish].

133. Turhan O, Senol Y, Baykul T, Saba R, Nevzat Yalcin A. Knowledge, attitudes and behaviour of students from a medicine faculty, dentistry faculty, and medical technology Vocational Training School toward HIV/ AIDS. Int J Occup Med Environ Health 2010;23(2): 153-60, 23 ref. DOI: 10.2478/v10001-010-0008-5.

134. Tyrpień M, Kasperczyk J, Jośko J, Mitręga K. Medical students' opinions on reproductive and therapeutic cloning. Probl Hig Epidemiol 2010;91(1):112-7, 11 ref. [in Polish].

135. Uścińska G. Some aspects of the implementation of the European Union social policy. EU citizenship and the individualization of social rights. Polit Spol 2010;37(4):2-7, 20 ref. [in Polish].

136. Uścińska G. Changes in the pension system in Poland. Changes in OPF. Projects of the Ministry of Labour and Social Policy. Polit Spol 2010;37(5-6):26-9, 9 ref. [in Polish].

137. Uścińska G. Social security schemes co-ordination as an instrument of development of freedom of movement of persons. New EU regulations. Polit Spol 2010;37 (11-12):1-5, 7 ref. [in Polish].

138. Wassel A, Nowakowska E, Bryl W, Kus K, Paczkowska A. Direct costs of hypertension treatment - primary study. Nadcisn Tetn 2010;14(6):460-73, 10 ref. [in Polish].

139. Wiśniewska-Śliwińska H. The voice in the discussion on the latest trends in health education. Probl Hig Epidemiol 2010;91(2):335-7, 17 ref. [in Polish].

140. Wojsa J, Jankowski A, Skalski M, Soszyński M. Medical Information Management System (MIMS) as the national part of the NATO MEDICS (Medical Information and Coordination System). Lek Wojsk 2010;88(2):176-9, 4 ref. [in Polish].
141. Wojtyła A, Biliński P, Jaworska-Łuczak B. Regulatory strategies to ensure food and feed safety in Poland update review. Ann Agric Environ Med 2010;17(2): 215-20, 10 ref.

142. Wyrębska A, Kałużewski B, Gałuszka M. Genetic counselling in the context of cancerous disease - patients' preferences concerning the way of presenting the size of morbidity risk. Med Ogolna 2010;16(2): 140-51, 11 ref. [in Polish].

143. Zajdel J, Górski P. The analysis the doctor-patient communication on the basis of selected clinical and demographic factors. Med Pr 2010;61(2):165-81, 34 ref. [in Polish].

144. Zajdel R, Krakowiak A, Zajdel J. The analysis of legal basis of telediagnosis and teleconsultation in clinical practice. Are we allowed to consult our patients via phone? Part I. Med Pr 2010;61(2):155-63, 17 ref. [in Polish].

145. Zajdel R, Zajdel J. The analysis of legal basis of telediagnosis and teleconsultation in clinical practice. Are we allowed to consult our patients via phone? Part II. Med Pr 2010;61(4):449-55, 12 ref. [in Polish].

146.Zejda JE, Wysocki MJ. Public health in research projects financed by the Ministry of Science and Higher Education - implementation and needs. Przegl Epidemiol 2010;64(3):405-11, 15 ref. [in Polish].

147. Ziemba J, Nowakowska-Głąb A, Wilczyński J, Maniecka-Bryła I, Nowakowska D. Knowledge of toxoplasmosis among pregnant women, midwifes, medical students and obstetricians. Med Pr 2010;61(3): 271-6, 8 ref. [in Polish].

148. Zubrzycki J, Małecka-Massalska T. Telemedicine medicine and technology in fight for our health. Zdrow Publiczne 2010;120(4):421-5, 10 ref. [in Polish].

149. Zużewicz K, Konarska M, Łuczak A. The issue of accidents among fleet drivers. Bezpiecz Pr 2010;9: 4-8, 7 ref. [in Polish].

150. Żaba C, Żaba Z, Marcinkowski JT, Helak C, Łapaj Ł, Stachowiak E. Analysis of sobriety status in casualties 
of fatal car accidents in the Poznan area based on autopsy protocols from the Chair and Department of Forensic Medicine, Poznan University of Medical Sciences between 2000-2009. Probl Hig Epidemiol 2010;91(2):291-7, 11 ref. [in Polish].

151. Żołnierczuk-Kieliszek D, Kulik TB, Pacian A, Janiszewska-Grzyb M. Health problems and quality of life of women at peri- and post-menopausal age. Med Ogolna 2010;16(2):184-91, 7 ref. [in Polish].

152. Żołnierczuk-Kieliszek D, Kulik TB, Wiktor H, Pacian A, Stefanowicz A. Influence of menopause and obstetric-gynaecological history on the quality of life in 45-65-year old women. Zdrow Publiczne 2010;120(3):234-8, 11 ref.

\section{ENVIRONMENTAL HAZARDS}

1. Brewczyński PZ, Anczyk E, Kasznia-Kocot J, Hom A, Muszyńska-Graca M, Dąbkowska B, et al. The know how of Hymenoptera biology particularly covering immunochemistry of their venom is of vital importance in contemporary environmental medicine. Part III. Family Formicidae. Med Srod 2010;13(1):99-111, 45 ref. [in Polish].

2. Chuturkova R, Iossifova Y, Clark S. Decrease in ambient air lead concentrations in Varna, Bulgaria, associated with the introduction of unleaded gasoline. Ann Agric Environ Med 2010;17(2):259-61, 19 ref.

3. Ćwiek-Ludwicka K. Hazards for health related to migration of substances from packaging into food. Rocz Panstw Zakl Hig 2010;61(4):341-7, 29 ref. [in Polish].

4. Gątarska A, Smoczyński S, Wypyska M. Effect of waterpipe network on the sensory quality of drinking water. Rocz Panstw Zakl Hig 2010;61(3):253-7, 15 ref. [in Polish].

5. Góralczyk K, Hernik A, Czaja K, Struciński P, Korcz W, Snopczyński T, et al. Organohalogen compounds new and old hazards for people. Rocz Panstw Zakl Hig 2010;61(2):109-17, 53 ref. [in Polish].
6. Grzesik J. The accoustical environment of human being. Med Srod 2010;13(4):27-33, 10 ref. [in Polish].

7. Iovdijova A, Bencko V. Potential risk of exposure to selected xenobiotic residues and their fate in the food chain - Part I: classification of xenobiotics. Ann Agric Environ Med 2010;17(2):183-92, 32 ref.

8. Jarosińska D. Climate change - a challenge for public health in Europe. Med Srod 2010;13(1):12-8, 15 ref. [in Polish].

9. Jędra M, Starski A. Benzene in food and human environment. Rocz Panstw Zakl Hig 2010;61(1):7-12, 23 ref. [in Polish].

10. Kaleta D, Polańska K, Wojtysiak P, Kozieł A, Kwaśniewska M, Miśkiewicz P, et al. Effective protection from exposure to environmental tobacco smoke in Poland: The World Health Organization perspective. Int J Occup Med Environ Health 2010;23(2): 123-31, 24 ref. DOI: 10.2478/v10001-010-0014-7.

11. Kołłątaj W, Szewczyk L. The influence of environmental pollution on bone tissue development and maintenance of the right structure and mineral content. Probl Hig Epidemiol 2010;91(1):1-4, 17 ref.

12. Krzywy I, Krzywy E, Pastuszak-Gabinowska M, Brodkiewicz A. Lead - is there something to by afraid of? Ann Acad Med Stetin 2010;56(2):118-28, 101 ref. [in Polish].

13. Kundzewicz ZW. Climate change and health in IPCC perspective. Med Srod 2010;13(1):7-11, 6 ref. [in Polish]. 14. Kurpas D, Hans-Wytrychowska A, Rudkowski Z. Possibility of the WHO Green Page Environmental Health Diagnostics implementation in primary care. Med Srod 2010;13(4):35-7, 3 ref.

15. Kwapuliński J, Nogaj E, Babula M, Suflita M. Influence of passive smoking on content of nickel in children pharyngeal tonsils. Med Srod 2010;13(3):23-30, 25 ref. [in Polish].

16. Langauer-Lewowicka H. Environmental exposure to vinyl chloride. Med Srod 2010;13(3):7-10, 27 ref. [in Polish]. 
17. Langauer-Lewowicka H, Brewczyński PZ. 60 years of Institute of Occupational Medicine and Environmental Health in Sosnowiec - activities for environmental health. Med Srod 2010;13(4):7-26, 113 ref. [in Polish].

18. Langauer-Lewowicka H, Pawlas K. Nickel - environmental allergen. Med Srod 2010;13(2):7-10, 30 ref. [in Polish].

19. Langauer-Lewowicka H, Pawlas K. Cadmium enironmental hazard. Med Srod 2010;13(2): 75-9, 37 ref. [in Polish].

20. Makles Z, Domański W. Chemical and biological hazards. Sorting municipal waste (1). Bezpiecz Pr 2010;3:22-5, 12 ref. [in Polish].

21. Makles Z, Domański W. Smoking tobacco products - active and passive chemical hazards. Bezpiecz Pr 2010;12:11-5, 15 ref. [in Polish].

22. Marzec S, Nowicka J, Janosik E. Solar ultraviolet radiation's hazard on the Upper Silesian province in view of Institute of Occupational Medicine and Environmental Health research. Med Srod 2010;13(4):38-44, 9 ref. [in Polish].

23. Michalska M, Bartoszewicz M, Cieszyńska M, Nowacki J. Bioaerosols on Tri-city (Gdańsk-Sopot-Gdynia) beaches. Int Marit Health 2010;61(1):41-3, 17 ref.

24. Michalska-Szymaszek M. The influence of temperature on survival, phenotype and antygen properties of Escherichia coli 0157 strains isolated from water and clinical material. Rocz Panstw Zakl Hig 2010;61(2): 213-9, 29 ref. [in Polish].

25. Mroczek B, Karakiewicz B, Brodowski J, Rotter I, Żułtak-Bączkowska K. Subjective health assessment and health behaviour of adult inhabitants of towns located in the vicinity of wind farms in Poland. Med Srod 2010;13(2):32-40, 20 ref. [in Polish].

26. Munoz Rodriguez AF, Silva Palacios I, Tormo Molina R. Influence of meteorological parameters in hourly patterns of grass (Poaceae) pollen concentration. Ann Agric Environ Med 2010;17(1):87-100, 69 ref.
27. Nogaj E, Kwapuliński J, Cecherz K, Misiołek M. Studies on determination of environmental and physiological levels of zinc ions in the pharyngeal tonsils. Med Srod 2010;13(1):65-71, 23 ref. [in Polish].

28. Olewińska E, Kowalska-Pawlak A, Kozłowska A, Kapka L, Pawlas K, Pawlas N. Frequency of SNP genetic polymorphisms in gamma-aminolevulinate dehydratase gene in population of children from Upper and Lower Silesia. Med Srod 2010;13(1):52-9, 28 ref. [in Polish].

29. Paldy A, Bobvos J. Climate change and health - challenges for Hungary. Med Srod 2010;13(1):19-29, 14 ref.

30. Pawlas K, Pawlas N. Noxious agents in closed space and their significant sources. Pr Zdrow Bezpiecz 2010;2: 1-4, 17 ref. [in Polish].

31. Perez-Badia R, Rapp A, Morales C, Sardinero S, Galan C, Garcia-Mozo H. Pollen spectrum and risk of pollen allergy in central Spain. Ann Agric Environ Med 2010;17(1):139-51, 52 ref.

32. Perez-Badia R, Vaquero C, Sardinero S, Galan C, Garcia-Mozo H. Intradiurnal variations of allergenic tree pollen in the atmosphere of Toledo (Central Spain). Ann Agric Environ Med 2010;17(2):269-75, 45 ref.

33. Potocki A, Helbin J. Anthropogenic food contamination. Med Srod 2010;13(1):112-22, 28 ref. [in Polish].

34. Prokopowicz A, Brewczyński PZ, Szuła M, Gała M, Pawlas N, Sobczak A. Toxicity of exhaust emissions from combustion of liquid biofuels and fuels with biocomponents. Med Srod 2010;13(3):68-76, 40 ref.

35. Prokopowicz A, Szuła M, Ociepińska M, Sobczak A. Indoor mercury vapor after accidental contamination by metallic mercury. Pr Zdrow Bezpiecz 2010;3-4:16, 17 ref. [in Polish].

36. Rodziewicz L, Zawadzka I. Determination of chloramphenicol residues in milk powder using molecular imprinted polymers (MIP) by LC-MS/MS. Rocz Panstw Zakl Hig 2010;61(3):249-52, 8 ref. [in Polish].

37. Roszko M, Szymczyk K. Determination of marker and dioxin-like polychlorinated biphenyls in grains of 
selected cereals and cereal products. Rocz Panstw Zakl Hig 2010;61(4):355-60, 18 ref. [in Polish].

38. Sagan M, Warchulińska J, Dec-Szlichtyng M, Lupa K, Jakubiak M. Spirometric assessment of the rural population of Rejowiec Commune. Zdrow Publiczne 2010;120(4):413-6, 21 ref.

39. Skotak K. Ozone concentration attributable premature death in Poland. Med Srod 2010;13(1):30-40, 18 ref. [in Polish].

40. Staśkiewicz G, Torres K, Czekajska-Chehab E, Pachowicz M, Torres A, Radej S, et al. Low atmospheric pressure and humidity are related with more frequent pulmonary embolism episodes in male patients. Ann Agric Environ Med 2010;17(1):163-7, 16 ref.

41. Strugała-Stawik H, Rudkowski Z, Pastuszek B, Morawiec K. Biomonitoring of lead in blood of children - short assessment of results 1991-2009. Med Srod 2010;13(3):11-4, 6 ref. [in Polish].

42. Święcicka D, Garboś S. Assessment of human health exposure connected with consumption of water characterized with elevated concentration level of silver released from jug water filter systems. Rocz Panstw Zakl Hig 2010;61(2):145-50, 14 ref. [in Polish].

43. Walczak A, Olszowski T, Wysokiński P, Wysiecki P, Szych Z. Tobacco smoking in twins' families and the prevalence of chosen allergic diseases. Probl Hig Epidemiol 2010;91(2):190-7, 26 ref. [in Polish].

44. Wiszniewski A. Normalization and optimization of air ionization levels in the atmosphere of populated areas. Med Pr 2010;61(2):241-51, 24 ref. [in Polish].

45. Wojciechowska-Mazurek M, Starska K, Mania M, Brulińska-Ostrowska E, Biernat U, Karłowski K. Monitoring of contamination of foodstuffs with elements noxious to human health. Part II. Mineral waters, soft drinks, fruits, nuts, rice, soybeans, fish and seafood. Rocz Panstw Zakl Hig 2010;61(1):27-35, 23 ref. [in Polish].

46. Wojtyła-Buciora P, Marcinkowski JT. Estimation of health risk resulting from excessive chemical parameters in drinking water. Probl Hig Epidemiol 2010;91(1): 137-42, 13 ref. [in Polish].

47. Zaciera M, Kurek J, Dzwonek L, Sobczak A, Brewczyński PZ. Indoor emission of chemical compounds from endogenous sources. Med Srod 2010;13(4):61-4, 18 ref. [in Polish].

48. Zwoździak A, Sówka I, Zwoździak J, TrzeplaNabaglo K. PM2.5 air pollution and the potential health risk evaluation in Wroctaw, Poland. Med Srod 2010;13(2):25-31, 17 ref. [in Polish].

This work is available in Open Access model and licensed under a Creative Commons Attribution-NonCommercial 3.0 Poland License - http://creativecommons.org/ licenses/by-nc/3.0/pl/deed.en. 